\title{
Early Cretaceous paleomagnetic results from Marie Byrd Land, West Antarctica: Implications for the Weddellia collage of crustal blocks
}

\author{
Vic DiVenere and Dennis V. Kent \\ Lamont-Doherty Earth Observatory and Department of Geological Sciences of Columbia University \\ Palisades, New York
}

Ian W. D. Dalziel

Institute for Geophysics, University of Texas at Austin

\begin{abstract}
A new 117 Ma paleomagnetic pole has been defined from the study of volcanic and plutonic rocks from the eastern portion Marie Byrd Land (MBL). The new pole $\left(185.6^{\circ} \mathrm{E} /\right.$ $56.8^{\circ} \mathrm{S}, A_{95}=8.7^{\circ}$ ) implies that the eastern portion of MBL was an integral part of Weddellia, which included the ancestral Antarctic Peninsula, Thurston Island, and Ellsworth-Whitmore Mountains blocks of West Antarctica. This pole is generally similar to a $\sim 125 \mathrm{Ma}$ pole from Thurston Island. Both poles call for major clockwise rotation and poleward motion of eastern MBL and Thurston Island between the Early Cretaceous (125-117 Ma) and the mid-Cretaceous (110-100 Ma). We propose that in the Early Cretaceous, eastern MBL and the Eastern Province of New Zealand were part of a continuous active Pacific margin of Gondwana, connecting with the Antarctic Peninsula, and distinct from western MBL, the Western Province of New Zealand, and North Victoria Land. These western terranes are thought to have accreted to Gondwana in the Devonian. Eastern MBL and the Eastern Province of New Zealand amalgamated with western MBL and the Western Province of New Zealand by the mid-Cretaceous. Major Early Cretaceous motions of the Weddellia blocks postdate the estimated initiation of seafloor spreading in the Weddell Sea and therefore may be the result of plate reorganization during the Cretaceous Quiet Zone.
\end{abstract}

\section{Introduction}

East Antarctica was the hub of cratonic Gondwana, from which South America and Africa, India, and Australia separated sequentially during Jurassic and Cretaceous times. The West Antarctic crustal provinces, largely the product of Phanerozoic tectonic and magmatic accretion on the Pacific margin of Gondwana, were profoundly affected by the changing plate tectonic regime as breakup proceeded. Marie Byrd Land (MBL) is one of the four major crustal blocks, along with Thurston Island (TI), Antarctic Peninsula (AP), and Ellsworth-Whitmore Mountains (EWM) (Figure 1), which presently make up West Antarctica [Dalziel and Elliott, 1982]. New Zealand, including the Campbell Plateau and Chatham Rise, was also part of West Antarctica until it rifted away in Late Cretaceous time.

The relative positions of the West Antarctic crustal blocks and their positions with respect to one another and the East Antarctic craton are fairly well known from the mid-Cretaceous to Recent from paleomagnetic studies [Grunow, 1993; DiVenere et al., 1994] and constraints from marine geophysical data between Marie Byrd Land and New Zealand [Mayes et al., 1990], the Ross Sea [Cooper et al., 1991], and

Copyright 1995 by the American Geophysical Union.

Paper number $95 \mathrm{JB} 00042$

0148-0227/95/95JB-00042\$05.00 the Weddell Sea [Barker and Lonsdale, 1991; Livermore and Woollett, 1993]. For earlier times, it is apparent that the West Antarctic blocks have experienced significant tectonic translations and rotations, particularly prior to and during the Jurassic and Early Cretaceous opening of the Weddell Sea [Watts and Bramall, 1981; Longshaw and Griffiths, 1983; Grunow et al., 1987a, 1987b, 1991; Grunow, 1993; Dalziel and Grunow, 1992]. However, it has been difficult to form a concise picture of the pre- mid-Cretaceous tectonic evolution due to the remoteness and scattered nature of the rock outcrops and attendant paucity of geological details and the small number of paleomagnetic studies.

Most previous plate tectonic reconstructions of West Antarctica have dealt primarily with the crustal blocks of the Weddell Sea sector (AP, TI, and EWM), collectively referred to as "Weddellia" by Grunow et al. [1987a], as recent work has progressed westward from the Scotia arc, and hence the largest number of paleomagnetic results are available for these. In paleogeographic reconstructions, MBL is usually left near to its present position close to the Transantarctic Mountains and North Victoria Land because of the similarity of Paleozoic rocks in western MBL and North Victoria Land. The $\sim 100 \mathrm{Ma}$ paleomagnetic results from MBL confirm a position for MBL near North Victoria Land at this time [DiVenere et al., 1994], but there have been no reliable pre-100 Ma paleomagnetic results for MBL. This has created the impression that MBL, and the then-attached New Zealand microcontinent, were not attached to, and have evolved separately from, Weddellia, even 


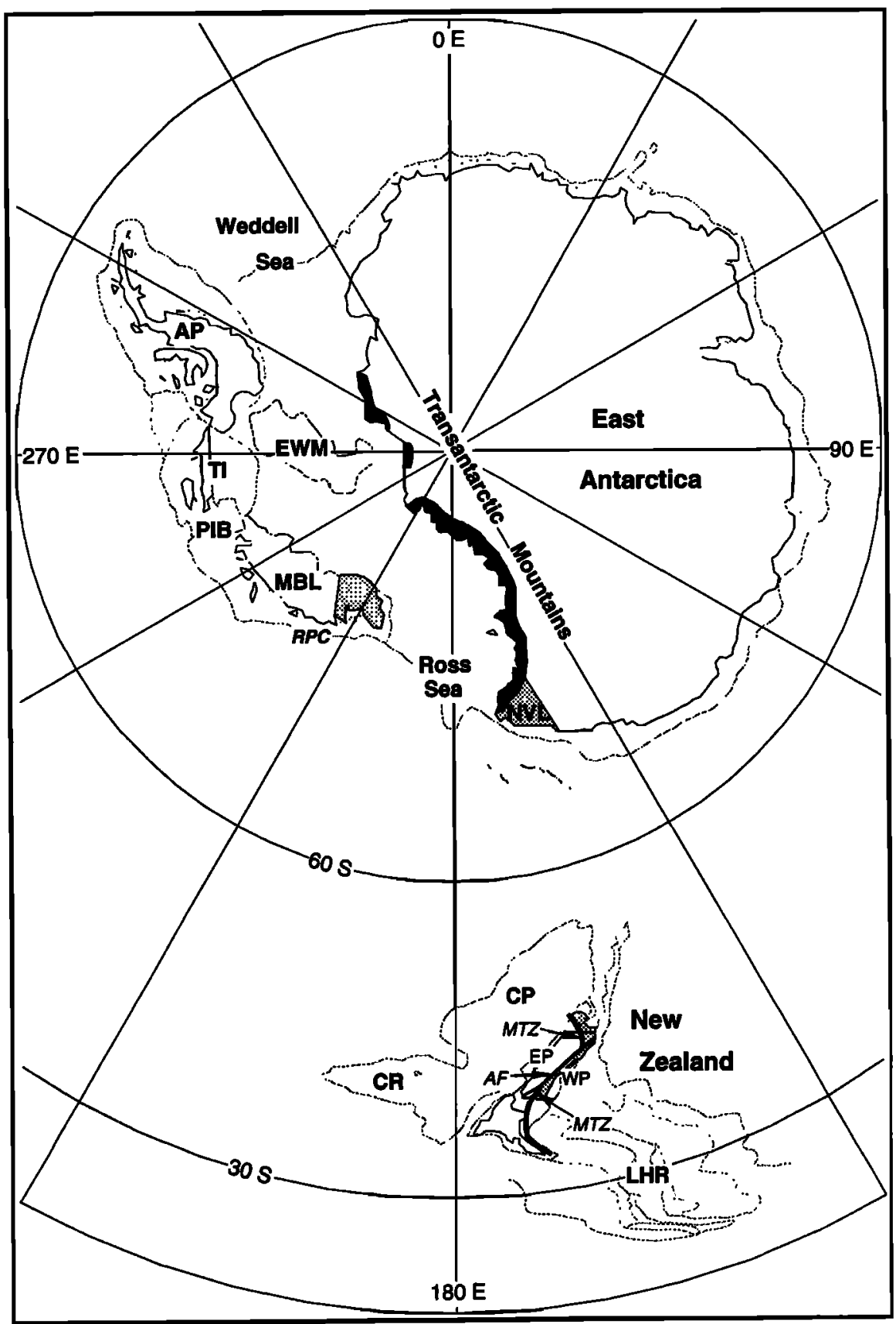

Figure 1. Map of Antarctica and New Zealand showing Marie Byrd Land (MBL), Thurston Island (TI), Antarctic Peninsula (AP), Ellsworth-Whitmore Mountains (EWM), North Victoria Land (NVL), Pine Island Bay (PIB), Ruppert/Hobbs Coast (RPC), Eastern Province of New Zealand (EP), Western Province of New Zealand (WP), Campbell Plateau (CP), Chatham Rise (CR), Lord Howe Rise (LHR), Median Tectonic Zone (MTZ; heavy solid line), the Alpine Fault (AF; medium solid line), and the Transantarctic Mountains (black shading). Gray stippled areas show the onshore extent of the presumed correlative lower Paleozoic turbidites and Devonian granodiorites.

though the Eastern Province of New Zealand appears to have been part of a continuous Gondwana convergent margin (arc, fore arc, and accretionary prism) extending from Chile through the Antarctic Peninsula to New Zealand during the midPaleozoic through Early Cretaceous [Dalziel and Grunow, 1985; Dalziel and Forsythe, 1985; Bradshaw, 1989; Tranter, 1991 ].

In this paper, new paleomagnetic data are presented from Lower Cretaceous volcanic and plutonic rocks from the
Ruppert and Hobbs Coast of MBL (Figure 2). Our interpretation of these results implies a pre- mid-Cretaceous position for at least this portion of $\mathrm{MBL}$, farther removed from its current position with respect to North Victoria Land. A plate tectonic reconstruction is presented, consistent with paleomagnetic data from West Antarctica and New Zealand, that links the accretionary complexes of AP and eastern New Zealand along the Pacific margin and places the magmatic arc rocks of MBL and TI inboard of these. 


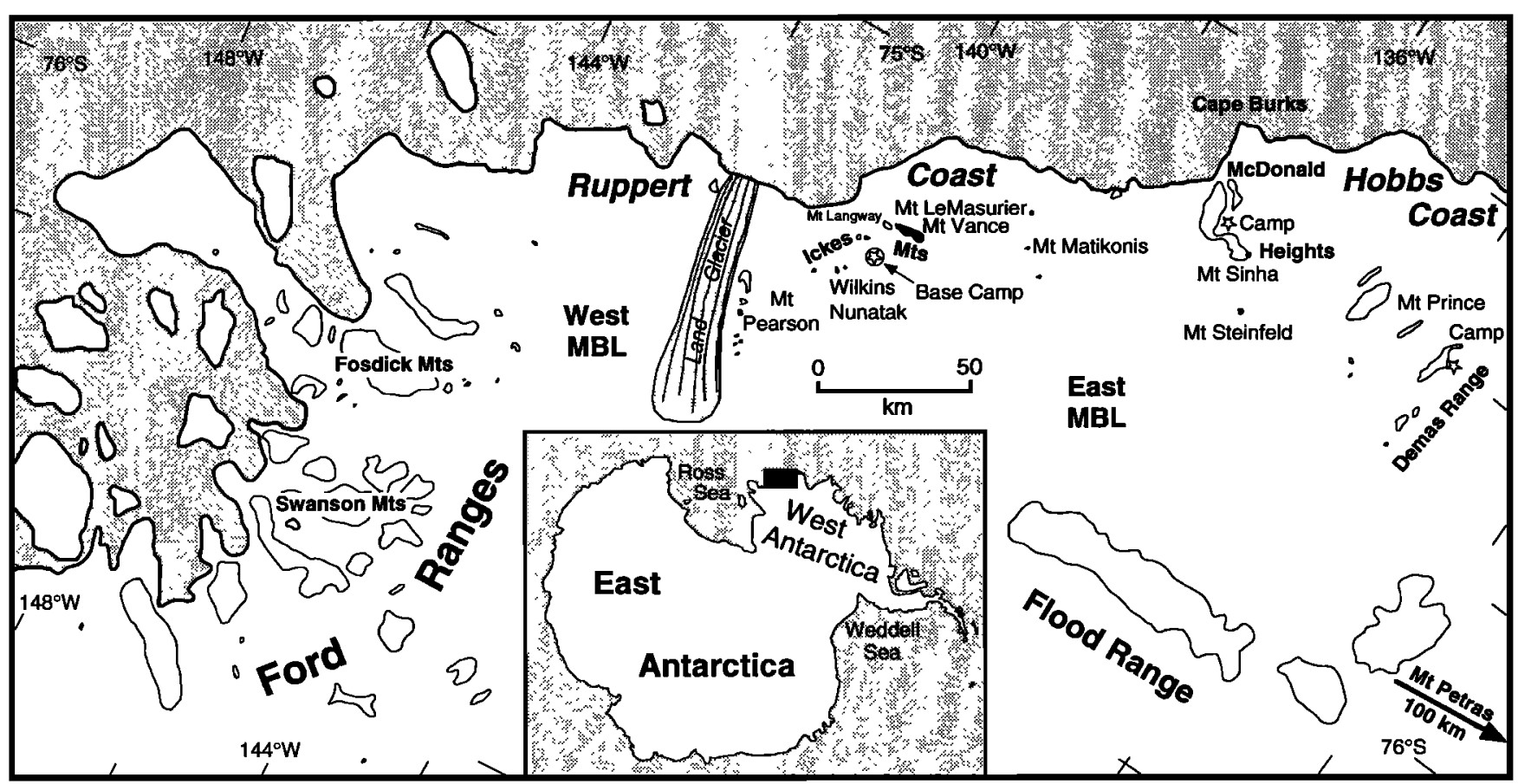

Figure 2. Locality map of the study area in Marie Byrd Land.

\section{Geological Background}

The geologic record of western MBL begins with a lower Paleozoic turbidite sequence, the Swanson Formation, which was folded and mildly metamorphosed in Late Ordovician time [Adams, 1986]. Similar rocks are found on Campbell Island of the southern Campbell Plateau as well as constituting the Greenland Group of western South Island, New Zealand [Adams, 1986]. The Robertson Bay Group of North Victoria Land, on the edge of the East Antarctic craton, is sedimentalogically similar to the Swanson Formation and Greenland Group [Bradshaw et al., 1983] and has often been correlated with them, although metamorphism in the rocks of MBL and New Zealand appears to postdate the CambroOrdovician Ross Orogeny in North Victoria Land by about 50 Ma [Adams, 1986]. In the Ford Ranges of western MBL (Figure 2), the Swanson Formation was intruded by the subduction related, I-type, Devonian-Carboniferous Ford Granodiorite [Weaver et al., 1991]. Similar Devonian igneous rocks are found in North Victoria Land (East Antarctica), Tasmania and Victoria (Australia), and the Western Province of South Island, New Zealand [Grindley and Davey, 1982; Adams, 1987; Mason and Taylor, 1987; Laird, 1991, Weaver et al., 1991]. The Robertson Bay and Bowers Terranes of North Victoria Land, along with New Zealand and MBL, are thought to have finally accreted to the East Antarctic craton in the late Paleozoic [Weaver et al., 1991; Borg and DePaolo, 1991; Laird, 1991]. However, neither the Swanson Formation nor Ford Granodiorite are found east of the Land Glacier $\left(141^{\circ} \mathrm{W}\right)$ in MBL (Figure 2), with the possible exception of a granodiorite at Mount McCoy directly adjacent to the east side of Land Glacier. This accretion event, therefore, may not necessarily apply to all of MBL. In this paper we will refer to the two portions of MBL, separated at approximately the Land Glacier, as East and West MBL.

In easternmost MBL, diorites, quartz diorites, and granodiorites have yielded K-Ar [Lopatin et al., 1974] and RbSr [Halpern, 1972] ages ranging from 225 to $295 \mathrm{Ma}$ (Permian/Triassic); work is currently in progress to test these 20-year old results. At face value, these rocks are broadly similar to a gabbro-diorite suite on Thurston Island, which has given a variety of ages ranging from about 230 to $290 \mathrm{Ma}$ $\left({ }^{40} \mathrm{Ar} /{ }^{39} \mathrm{Ar}, \mathrm{K}-\mathrm{Ar}\right.$, and Rb- Sr; [Pankhurst et al., 1993]). On Thurston Island, these plutons were intruded into an Upper Carboniferous granodiorite-gneiss; the parental magmas for both were emplaced in a convergent margin setting [Pankhurst et al., 1993; Leat et al., 1993]. This might be taken to suggest the continuity, or at least the proximity, of eastern MBL and TI since late Paleozoic times. Additionally, orthogneiss on the Bear Peninsula of eastern MBL with a $\sim 470 \mathrm{~K}$-Ar age [Lopatin et al., 1974] and gneiss on Clarke Island on the TI side of Pine Island Bay (preliminary Rb-Sr age of $\sim 445 \mathrm{Ma}$ ( $R$. J. Pankhurst, personal communication, 1993)) may suggest a relationship between these two areas as far back as early Paleozoic times.

The Swanson Formation and Ford Granodiorite of West MBL, as well as the Permian granodiorites of East MBL and TI, are intruded by Mesozoic granitoids. Lower Cretaceous subduction-related igneous rocks in MBL (the subject of this study) and New Zealand change abruptly to A-type igneous rocks between about 110 and $105 \mathrm{Ma}$ [Spörli and Craddock, 1981; Weaver and Pankhurst, 1991; Weaver et al., 1992; Palais et al., 1993; Weaver et al., 1994], apparently as a result of subduction of the Pacific-Phoenix Ridge [Bradshaw, 1989] and the beginning of rifting between MBL and New Zealand. Seafloor spreading between MBL and New Zealand began shortly before Chron 34 (84 Ma) [Mayes et al., 1990]. In MBL, an erosional surface developed on Cretaceous and older rocks is overlain by upper Tertiary alkaline volcanic rocks [LeMasurier and Rex, 1983, 1991] that are proposed to be the result of a mantle plume [Hole and LeMasurier, 1994]. 


\section{Sampling and Techniques}

Oriented samples were collected for paleomagnetic study from all major exposed pre-Cenozoic rock units on the Ruppert and Hobbs Coast area of Marie Byrd Land. A paleomagnetic study of mid-Cretaceous ( $100 \mathrm{Ma})$ rocks was reported by DiVenere et al. [1994]. In this paper we describe Lower Cretaceous paleomagnetic results from 189 oriented cores collected at 25 sites in volcanic rocks from the col between Mount Vance and Mount LeMasurier, and also from Mount Pearson, Mount Matikonis, and Wilkins Nunatak on the Ruppert Coast (17 sites), and from a granodiorite suite at Mount Sinha and Mount Steinfeld in the McDonald Heights area of the Hobbs Coast (eight sites) (Figure 2). Unpublished $\mathrm{Rb}-\mathrm{Sr}$ data have given $\sim 110$ to $120 \mathrm{Ma}$ ages for the volcanic units and $118 \pm 2 \mathrm{Ma}$ for the granodiorite suite (R. J. Pankhurst, personal communication, 1993). Unpublished zircon U-Pb data also give an age of about $117 \mathrm{Ma}$ for the granodiorite at Mount Steinfeld (S. B. Mukasa, personal communication, 1993). Most of the volcanic rocks are thermally metamorphosed, and contacts are observed at Mount Vance/LeMasurier and Wilkins Nunatak with intruding $\sim 100$ Ma syenite and alkali granite from which paleomagnetic results were reported by DiVenere et al. [1994].

The cores were taken with a portable gasoline-powered drill and were oriented with a magnetic compass. All magnetic readings were checked with a sun compass at Mount Pearson, Mount Sinha and Mount Steinfeld, and three sun compass readings were also taken at Wilkins Nunatak. No sun compass checks could be made at Mount Matikonis or at Vance/LeMasurier because clouds or outcrop shadows prevented it. Magnetic variation was calculated for each site from the International Geomagnetic Reference Field [Langel, 1992], and appropriate corrections were applied to the field data. Differences between the magnetic and sun compass readings were within $2^{\circ}$ to $3^{\circ}$ and the magnetic compass readings were used for the core orientations. All samples were subjected to either progressive thermal demagnetization to maximum temperatures of $675^{\circ} \mathrm{C}$, or progressive alternating field (AF) demagnetization to maximum fields of $100 \mathrm{mT}$. Both demagnetization methods were used for each site. Specimen directional behavior was similar under both methods, though thermal demagnetization tended to give better results for the granodiorites while AF demagnetization gave good results in the volcanic rocks. Measurements were made on an ScT two-axis cryogenic magnetometer, or a Digico spinner magnetometer for very strongly magnetized samples. Bulk magnetic susceptibility was monitored using a Bartington susceptibility bridge for all specimens after each thermal demagnetization step. Curie point determinations were made on a horizontal beam Curie balance. Sample storage, demagnetization, and cryogenic magnetometer measurements were performed in a magnetically shielded room with a nominal ambient field of $\sim 250 \mathrm{nT}$. Additional shielding of the field demagnetizers and the cryogenic magnetometer reduces the field to less than $5 \mathrm{nT}$ over the sample space.

Magnetic component directions were calculated by principal component analysis [Kirschvink, 1980] of linear segments chosen by inspection from orthogonal plots [Zijderveld, 1967]. The components thus determined were plotted on equal-area nets, and mean directions were determined by standard Fisher statistics [Fisher, 1953].
Virtual geomagnetic poles (VGPs) were calculated for each site and mean paleomagnetic poles and their associated confidence limits were calculated from these. All tests of significance between poles were made using the formal method of McFadden and Lowes [1981] at the 95\% confidence level $(p=$ 0.05 ).

\section{Paleomagnetic Results From Ruppert Coast Volcanics}

\section{Mount Vance/LeMasurier Volcanics}

Forty-four oriented cores were collected at six sites from three units in the $\sim 117 \mathrm{Ma}$ Mount Vance/LeMasurier volcanics: two sites each in a basal felsic agglomerate, a 10m-thick feldspar porphyry, and a thick pile of amygdaloidal volcanic flows ranging from alkaline basalt to trachyte in composition (S. D. Weaver, personal communication, 1993). Heavy overcast did not allow sun compass readings to be taken. The volcanic rocks have been hydrothermally altered. The bedding dips gently to the north and strikes east-west (sites 1 to 4: strike/dip $=281^{\circ} / 10^{\circ} \mathrm{N}$, sites 5 and 6: strike/dip $\left.=265^{\circ} / 20^{\circ} \mathrm{N}\right)$. The rocks are strongly magnetized, with intensities of the natural remanent magnetization (NRM) ranging from 0.5 to $20 \mathrm{~A} / \mathrm{m}$, but with most samples from 1 to $3 \mathrm{~A} / \mathrm{m}$. After weak spurious magnetizations are removed, usually in the first treatment step (i.e., $10 \mathrm{mT}$ or $100^{\circ} \mathrm{C}$ ), a stable characteristic remanent magnetization (ChRM) is identified by the linear decay to the origin with further treatment (Figures 3b, 3c). Samples are not quite completely demagnetized by $100 \mathrm{mT}$ (Figure 3c) and maximum unblocking temperatures and Curie temperatures for most samples are concentrated near $585^{\circ} \mathrm{C}$ (Figure 3d). These characteristics are consistent with magnetite as the main carrier of the magnetic remanence. No large-scale changes are seen in bulk susceptibility, and therefore magnetic mineralogy, during thermal treatment. The stable components are uniformly of normal polarity, and in situ directions are generally easterly directed with moderately steep negative inclination, and southeasterly and steep after a bedding tilt correction is applied (Figures 3e, 3f).

Four of the six samples from site 1 in the volcanic agglomerate are completely resistant to AF demagnetization to $100 \mathrm{mT}$ and have maximum unblocking temperatures and Curie temperatures around $680^{\circ} \mathrm{C}$ (Figure 3a), consistent with remanence carried by hematite. The in situ mean direction for the four hematite bearing samples (declination $(\mathrm{dec})=0.3$, inclination (inc) $=-82.5$, and $a_{95}=13.6^{\circ}$ ) is similar to the in situ mean direction of the intruding $\sim 100$ Ma syenite (dec = 349.1 , inc $=-75.1$, and $a_{95}=2.6^{\circ}$ ) [DiVenere et al., 1994]. Site 1 was sampled in the volcanics nearest the contact with the intruding syenite; the four hematite bearing samples from this site appear to have been thermochemically remagnetized as a result of the emplacement of the syenites at about $100 \mathrm{Ma}$.

A mean ChRM direction was calculated for the Mount Vance/LeMasurier volcanics from the six magnetite-bearing site mean directions (excluding the four hematite-bearing samples from site 1). The in situ mean direction ( $\mathrm{dec}=59.9$, inc $=-77.9, a_{95}=5.5^{\circ}$ ) is significantly different from the axial dipole field (dec $=0$, inc $=-82.6$ ). Although the mean is not significantly different from the present-day field $(\mathrm{dec}=75.3$, inc $=-75.7)$ at the $95 \%$ confidence level, the high stability of the magnetization, as demonstrated by thermal and alternating 


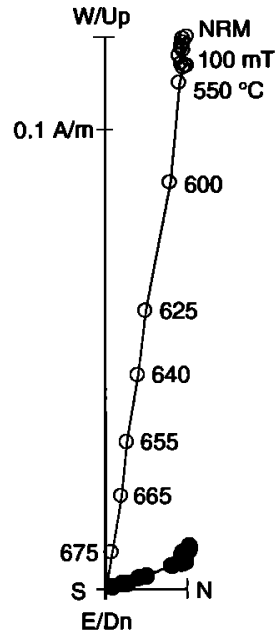

(a) MB 304.1.3

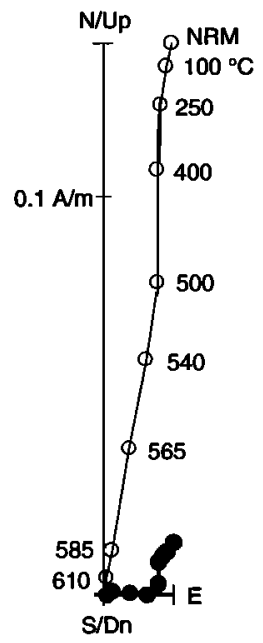

(b)

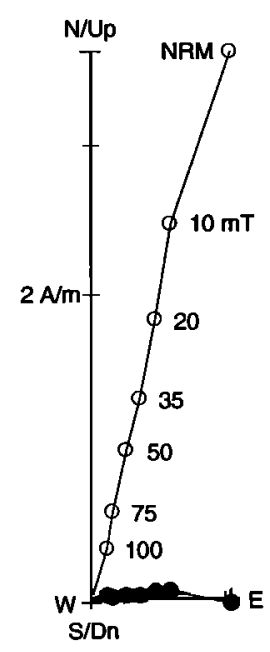

(c) $\mathrm{MB} 304.5 .1$
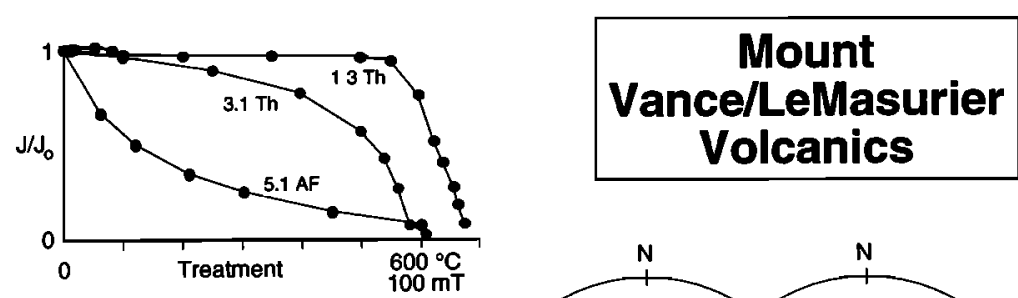

(a)

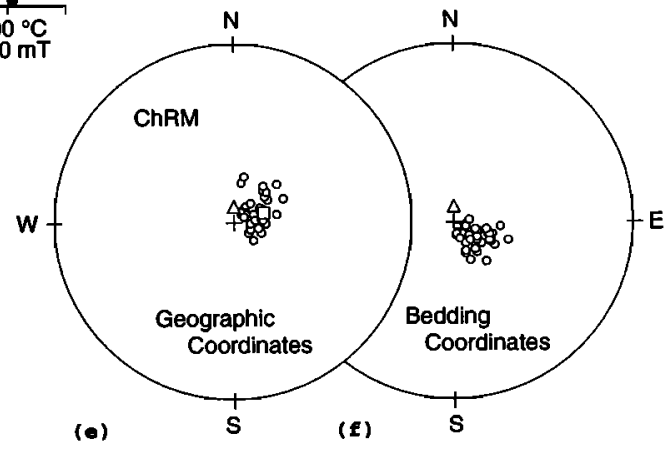

Figure 3. (a-c) Orthogonal plots of demagnetization data from Mount Vance/LeMasurier volcanics, with open symbols representing the vertical trace and solid symbols the horizontal trace of the magnetization vector; (d) remanent intensity (normalized to initial intensity) versus sample treatment; (e) equal-area projection of sample ChRM component directions before and (f) after correcting for tilt of the volcanic layering, with open symbols plotting on the upper hemisphere. Triangle represents the time-averaged dipole field direction for this location; square is the present-day field direction.

field experiments, should preclude that these rocks are carrying a recent viscous magnetization. The bedding attitudes are slightly different for sites 1 to 4 as compared to sites 5 and 6 , but the difference is not great enough to serve as the basis for a fold test. The bedding tilt corrected mean direction is dec $=125.2$, inc $=-78.0$, and $a_{95}=4.8^{\circ}$, with a marginal increase in the precision parameter after bedding tilt correction (Table 1). However, the ChRM mean directions (before and after tilt correction) for the $\sim 117 \mathrm{Ma}$ volcanics are significantly different from the mean direction of the intruding $\sim 100 \mathrm{Ma}$ Ickes Mountains syenite $(\mathrm{dec}=265.2$, inc $=-87.1$, $a_{95}=2.6^{\circ}$, in situ [DiVenere et al., 1994]).

The angular dispersion of the site mean virtual geomagnetic poles (VGPs) $\left(10.5^{\circ}+6^{\circ} /-2.8^{\circ}\right)$ is less than the expected dispersion of the field (about $20^{\circ}$ ) at the paleolatitude of Mount Vance $\left(67^{\circ} \mathrm{S}\right)$ [McFadden et al., 1991]. Therefore, if the site means represent spot readings of the field, then our six sites may not have adequately sampled secular variation of the field. However, it seems likely that secular variation has been at least partially averaged within-site due to hydrothermal alteration in the volcanic pile [Ade-Hall et al., 1971], as evidenced by infilling of vessicles in the basalts (assuming this alteration did, in fact, occur at the time of the extrusion of these rocks), and an extended period of elevated temperatures, as evidenced by the high Curie temperatures, implying the oxidation/exsolution of the primary titanomagnetite.

\section{Wilkins Nunatak}

Forty-five oriented cores were collected at six sites in lavas and volcaniclastic sediments on both limbs of an antiform structure at Wilkins Nunatak, located approximately $20 \mathrm{~km}$ SSW of Mount Vance/LeMasurier. The volcanic rocks are intruded by $\sim 100 \mathrm{Ma}$ alkali granite and syenite, which are 
found throughout the Ruppert/Hobbs Coast, and are strongly metamorphosed, probably due to the mid-Cretaceous intrusion.

The intensity of NRM ranges from about $10^{-3}$ to $1 \mathrm{~A} / \mathrm{m}$. Progressive AF or thermal demagnetization to 10 to $15 \mathrm{mT}$ or 300 to $400^{\circ} \mathrm{C}$ removes unstable viscous magnetizations. At higher treatment levels, all samples yield a steep negative inclination, normal polarity magnetization before tilt correction. Unblocking temperature and coercivity curves (Figures 4a, 4b, 4d) show that most samples contain magnetizations stable to 575 to $585^{\circ} \mathrm{C}$ or 70 to $100 \mathrm{mT}$, consistent with magnetite as the principal carrier of remanence. Sample directions calculated from the high treatment segments of demagnetization trajectories are shown before and after tilt correction in Figures $4 \mathrm{e}$ and $4 \mathrm{f}$.

The directions from the two limbs become dispersed after restoring the limbs to the horizontal. This appears to indicate that the magnetization was acquired after folding. However, the directions are not very well defined in many samples, and in some there is an indication (curving demagnetization

Table 1. Site Mean Directions and South Paleomagnetic Poles

\begin{tabular}{|c|c|c|c|c|c|c|c|c|}
\hline \multirow[b]{2}{*}{ Site } & \multirow[b]{2}{*}{$n / N$} & \multirow[b]{2}{*}{$k$} & \multirow[b]{2}{*}{$a_{95}$} & \multicolumn{2}{|c|}{ Direction } & \multicolumn{2}{|c|}{ Pole } & \multirow[b]{2}{*}{$A_{95}$} \\
\hline & & & & $\begin{array}{l}\text { In Situ } \\
\text { Dec/Inc }\end{array}$ & $\begin{array}{l}\text { Tilt-Corrected } \\
\text { Dec/Inc }\end{array}$ & $\begin{array}{l}\text { In Situ } \\
\text { Lon/Lat }\end{array}$ & $\begin{array}{l}\text { Tilt-Corrected } \\
\text { Lon/Lat }\end{array}$ & \\
\hline \multicolumn{9}{|c|}{ Mount Vance/LeMasurier Volcanics (Lon/Lat 220.60/-75.47) } \\
\hline MB304.1 & $4 / 6^{a}$ & 1096 & 2.8 & $35.5 /-81.2$ & $129.8 /-85.9$ & - & $202.5 /-69.2$ & \\
\hline MB304.2 & $8 / 10$ & 132 & 4.8 & $88.9 /-78.7$ & $135.2 /-76.6$ & - & $190.5 /-52.9$ & \\
\hline MB304.3 & $7 / 7$ & 342 & 3.3 & $78.6 /-83.0$ & $149.2 /-80.2$ & - & $202.4 /-57.7$ & \\
\hline MB304.4 & $6 / 6$ & 1038 & 2.1 & $75.7 /-78.4$ & $126.2 /-78.4$ & - & $186.3 /-57.1$ & \\
\hline MB304.5 & $7 / 7$ & 119 & 5.6 & $49.2 /-71.9$ & $116.4 /-72.8$ & - & $173.7 /-49.9$ & \\
\hline MB304.6 & $6 / 7$ & 124 & 6.0 & $48.4 /-70.3$ & $111.2 /-72.4$ & - & $169.2 /-50.3$ & \\
\hline Mean is & $6 / 6$ & 149 & 5.5 & $59.9 /-77.9$ & - & $138.1 /-70.0$ & - & 9.8 \\
\hline Mean $t c$ & $6 / 6$ & 193 & 4.8 & - & $125.2 /-78.0$ & - & $185.6 /-56.8$ & 8.7 \\
\hline MB304.1 (ht) ${ }^{b}$ & $4 / 4$ & 47 & 13.6 & $0.3 /-82.5$ & $220.1 /-87.1$ & - & $232.0 /-70.6$ & \\
\hline \multicolumn{9}{|c|}{ Wilkins Nunatak Volcanics (Lon/Lat 220.05/-75.65)c } \\
\hline MB302.9 & $6 / 6$ & 40 & 10.8 & $15.3 /-88.7$ & $8.8 /-12.3$ & $216.8 /-78.1$ & - & \\
\hline MB302.10 & $6 / 6$ & 35 & 11.5 & $322.8 /-87.3$ & $6.6 /-11.6$ & $237.9 /-79.4$ & - & \\
\hline $\mathrm{MB302.14}$ & $8 / 8$ & 91 & 5.8 & $102.3 /-79.1$ & $19.8 /-13.9$ & $171.0 /-62.2$ & - & \\
\hline MB302.11 & $7 / 8$ & 78 & 6.9 & $15.1 /-81.2$ & $279.3 /-72.7$ & $102.9 /-85.0$ & - & \\
\hline MB302.12 & $7 / 7$ & 212 & 4.2 & $356.1 /-80.8$ & $280.0 /-69.7$ & $21.2 /-86.3$ & - & \\
\hline MB302.13 & $10 / 10$ & 108 & 4.7 & $30.1 /-87.5$ & $282.4 /-68.9$ & $206.3 /-79.6$ & - & \\
\hline MB302.14t $t c^{d}$ & & & & & $142.8 /-72.2$ & - & $192.5 /-45.1$ & \\
\hline \multicolumn{9}{|c|}{ Mount Matikonis Volcanics (Lon/Lat 221.18/-75.35) } \\
\hline MB210.1 & $10 / 7^{e}$ & 457 & 2.3 & $11.2 /-82.2$ & - & $123.4 /-87.0$ & - & \\
\hline MB210.2 & $14 / 7^{e}$ & 157 & 3.2 & $353.4 /-80.5$ & - & $12.4 /-85.6$ & - & \\
\hline Mean & $2 / 2$ & - & - & $1.4 /-81.5$ & - & $52.5 /-87.8$ & - & \\
\hline \multicolumn{9}{|c|}{ Mount Pearson Volcanics (Lon/Lat 219.03/-75.90) } \\
\hline MB207.1 & $6 / 7$ & 67 & 8.2 & $263.3 /-82.9$ & $319.4 /-72.4$ & $261.2 /-69.1$ & - & \\
\hline MB207.2 & $8 / 14$ & 77 & 6.4 & $302.7 /-76.0$ & $322.9 /-62.8$ & $311.5 /-67.9$ & - & \\
\hline MB207.4 & $7 / 10$ & 296 & 3.5 & $250.0 /-73.3$ & $232.4 /-71.1$ & $270.9 /-52.0$ & - & \\
\hline Mean & $3 / 3$ & 104 & 12.4 & $271.7 /-78.5$ & - & $279.3 /-64.4$ & - & 22.4 \\
\hline MB207.3 $(\mathrm{dk})^{f}$ & $3 / 1^{g}$ & 395 & 6.2 & $134.3 /-85.4$ & - & $201.0 /-68.5$ & - & \\
\hline \multicolumn{9}{|c|}{ Mount Steinfeld Granodiorite (Lon/Lat 224.13/-75.20) } \\
\hline MB203.1 & $7 / 7$ & 27 & 11.7 & $157.1 /-66.1$ & - & $205.9 /-34.6$ & - & \\
\hline MB203.2 & $6 / 6$ & 87 & 7.2 & $165.7 /-62.5$ & - & $212.3 /-29.4$ & - & \\
\hline MB203.3 & $6 / 7$ & 21 & 14.9 & $163.1 /-68.4$ & - & $211.0 /-37.4$ & - & \\
\hline MB203.4 & $6 / 7$ & 70 & 8.0 & $148.8 /-72.7$ & - & $201.4 /-44.8$ & - & \\
\hline MB203.5 & $7 / 7$ & 68 & 7.4 & $163.5 /-69.0$ & - & $211.4 /-38.2$ & - & \\
\hline Mean & $5 / 5$ & 325 & 4.2 & $160.3 /-67.8$ & - & $208.6 /-36.9$ & - & 6.3 \\
\hline
\end{tabular}


Table 1. (continued)

\begin{tabular}{|c|c|c|c|c|c|c|c|c|}
\hline \multirow[b]{2}{*}{ Site } & \multirow[b]{2}{*}{$n / N$} & \multirow[b]{2}{*}{$k$} & \multirow[b]{2}{*}{$a_{95}$} & \multicolumn{2}{|c|}{ Direction } & \multicolumn{2}{|c|}{ Pole } & \multirow[b]{2}{*}{$A_{95}$} \\
\hline & & & & $\begin{array}{l}\text { In Situ } \\
\text { Dec/Inc }\end{array}$ & $\begin{array}{l}\text { Tilt-Corrected } \\
\text { Dec/Inc }\end{array}$ & $\begin{array}{l}\text { In Situ } \\
\text { Lon/Lat }\end{array}$ & $\begin{array}{c}\text { Tilt-Corrected } \\
\text { Lon/Lat }\end{array}$ & \\
\hline \multicolumn{9}{|c|}{ Mount Sinha Granodiorite (Lon/Lat 223.85/-75.00) } \\
\hline MB 159.1 & $2 / 7$ & - & - & $324.1 /-83.3$ & - & $285.4 /-81.2$ & - & \\
\hline MB 159.2 & $5 / 7$ & 103 & 7.6 & $259.9 /-78.3$ & - & $275.0 /-61.0$ & - & \\
\hline MB 159.3 & $6 / 7$ & 152 & 5.5 & $254.6 /-76.5$ & - & $274.3 /-57.3$ & - & \\
\hline Mean & $3 / 3$ & 141 & 10.4 & $269.6 /-80.5$ & - & $276.0 /-66.5$ & - & 20.0 \\
\hline Mean $t c^{h}$ & & & & & $178.1 /-70.6$ & - & $222.1 /-40.1$ & 17.5 \\
\hline
\end{tabular}

$n / N$, number of samples accepted/number collected for site means or number of sites accepted over number of sites collected for group means; $k$, Fisher's precision parameter; $a_{95}$, radius of $95 \%$ cone of confidence about mean direction; Dec, mean declination; Inc, mean inclination; Lon, mean paleomagnetic pole east longitude; Lat, mean paleomagnetic pole north latitude (negative is south latitude); $A_{95}$, radius of $95 \%$ cone of confidence about mean pole; is, in situ; $t c$, tilt-corrected.

a Four specimens from two of six samples.

Hematite-bearing sample directions ( $100 \mathrm{Ma}$ ).

Sites $.9, .10$, and .14 are west end volcanics; .11, .12,

and .13 are east end volcaniclastics.

Specimens/samples.

Dike.

Specimens/hand sample.

Mean corrected for post- $100 \mathrm{Ma} 12^{\circ}$ southward tilt.

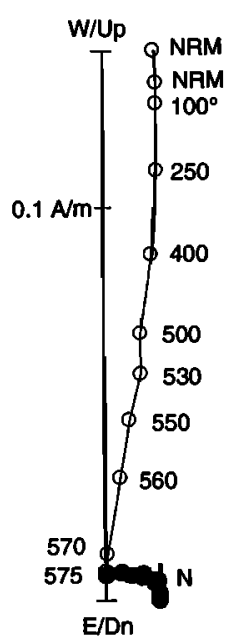

(a) MB 302.12.6

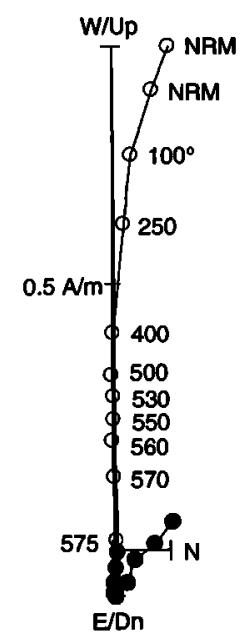

(b) MB 302.14.3

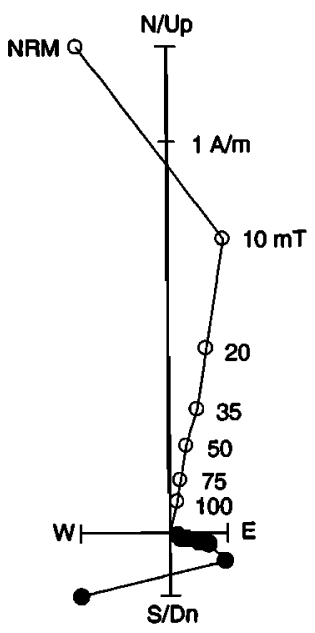

(c) $\quad \mathrm{MB} 302.14 .4$

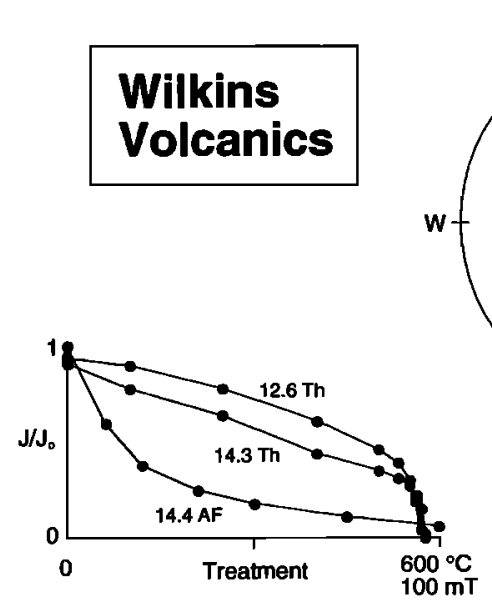

(d)

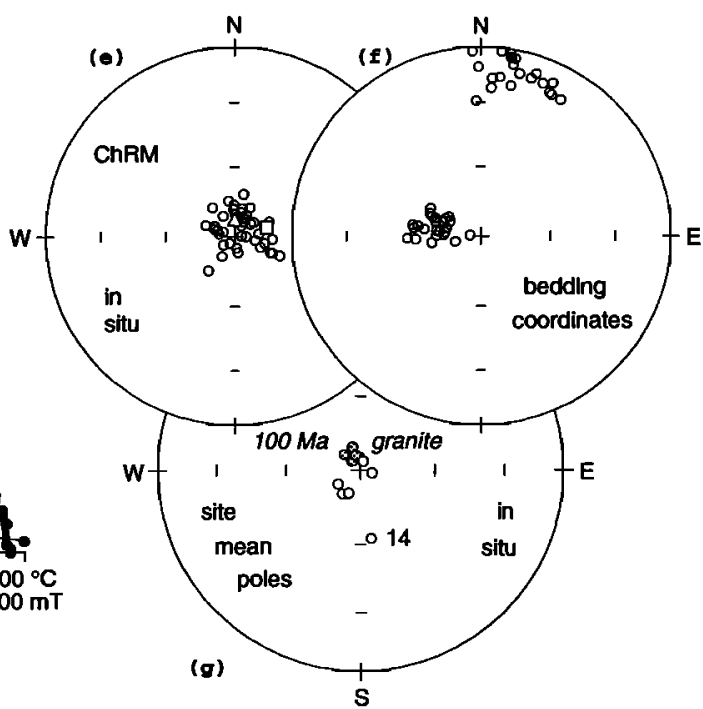

Figure 4. (a-c) Orthogonal plots of demagnetization data from Wilkins Nunatak volcanics; (d) intensity versus sample treatment; (e) equal-area projection of ChRM component directions before and (f) after tilt correction; (g) site mean poles plotted with the Wilkins $100 \mathrm{Ma}$ granite poles (grayed symbols). All other symbols defined as in Figure 3. 


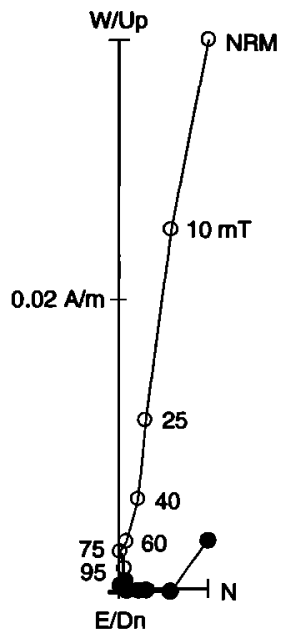

(a)

MB 210.1.6

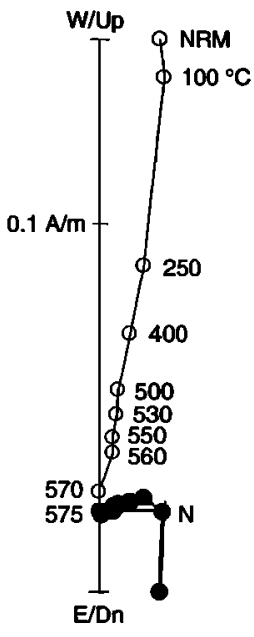

(b) MB 210.2.3t

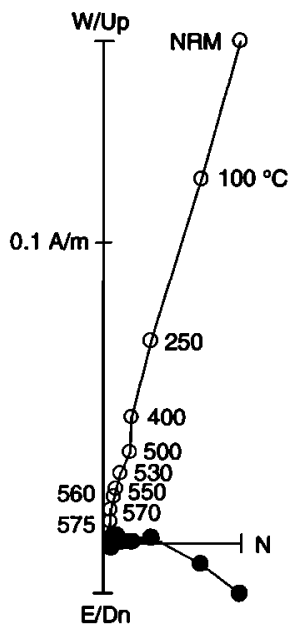

(c) $\quad \mathrm{MB} 210.2 .2 \mathrm{t}$

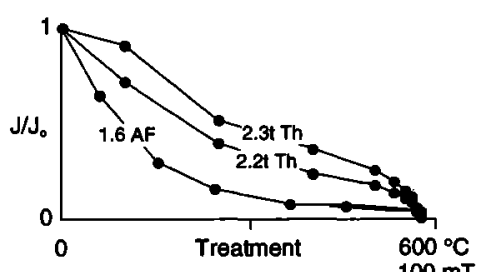

\section{Mt Matikonis Volcanics}

(d)

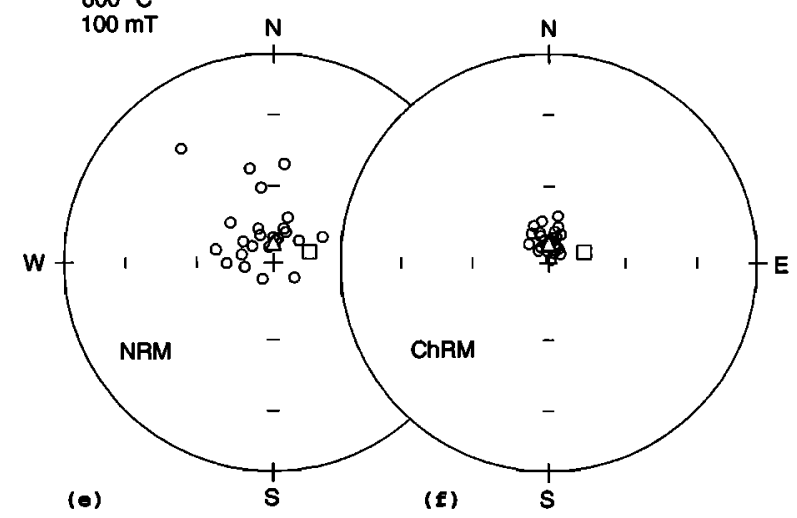

Figure 5. (a-c) Orthogonal plots of demagnetization data from Mount Matikonis volcanics; (d) intensity versus sample treatment; (e) equal-area projection of sample NRM directions and (f) ChRM component directions. All symbols defined as in Figure 3.

trajectories) of the simultaneous removal of more than one component of magnetization. Poles were calculated from each site mean direction and are compared with site mean poles from the intruding $100 \mathrm{Ma}$ granite in Figure 4g. Sites 11 and 12, with weak stable behavior, fall in one group with the granite means; sites 9,10 , and 13 , with intermediate NRM intensities and complicated high treatment behavior, fall in a second group somewhat farther from the granite means; and site 14 , with strong, stable behavior, is distinctly different from the granite means (Figure $4 \mathrm{~g}$ ). This is taken as evidence that sites 11,12 , and 13 in volcaniclastic sedimentary rocks, and sites 9 and 10 in volcanic flows, have been largely remagnetized due to the granite intrusion, while site 14 , the farthest removed from the visible contact with the granite, retains a more-or-less unaffected early (pre-100 Ma) magnetization. The mean direction for site 14 is dec $=102.3$, inc $=-79.1, a_{95}=5.8^{\circ}$ in situ (Table 1 ).

\section{Mount Matikonis}

Fourteen oriented cores were collected from two sites in thermally metamorphosed, bedded volcaniclastic rocks at Mount Matikonis, $40 \mathrm{~km}$ NE of Mount Vance/LeMasurier. The intensity of the NRM is of the order of $0.1 \mathrm{~A} / \mathrm{m}$. NRM directions are moderately scattered, but removal of lowstability components during progressive demagnetization yields well-grouped, steep upward, normal polarity directions (Figures 5e, 5f). Coercivities and maximum blocking temperatures are consistent with magnetite as the primary remanence-carrying mineral. The steep northerly direction (mean dec $=1.4$, inc $=-81.5$ ) is similar to the overprint direction seen in the results from Wilkins Nunatak (Table 1). Given this similarity and the relatively high grade of metamorphism at this location, these results may also represent an overprint acquired at about $100 \mathrm{Ma}$. 


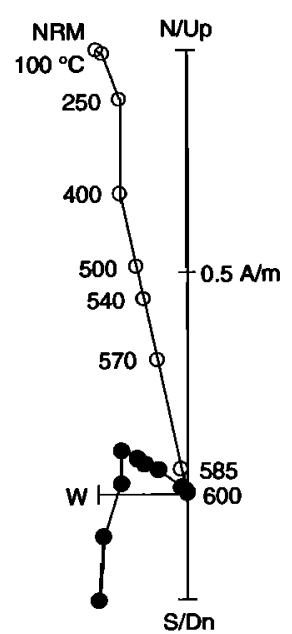

(a) MB 207.1.2

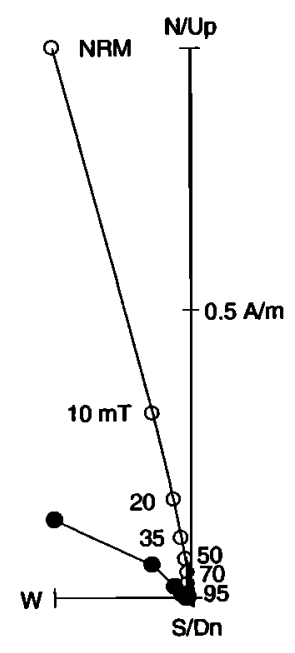

(b) $\quad$ MB 207.2.1

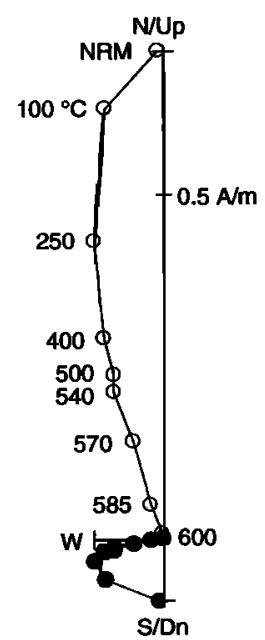

(c)

MB 207.4.4

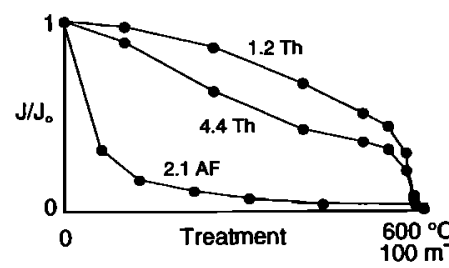

\section{Mt Pearson Volcanics}

(d)

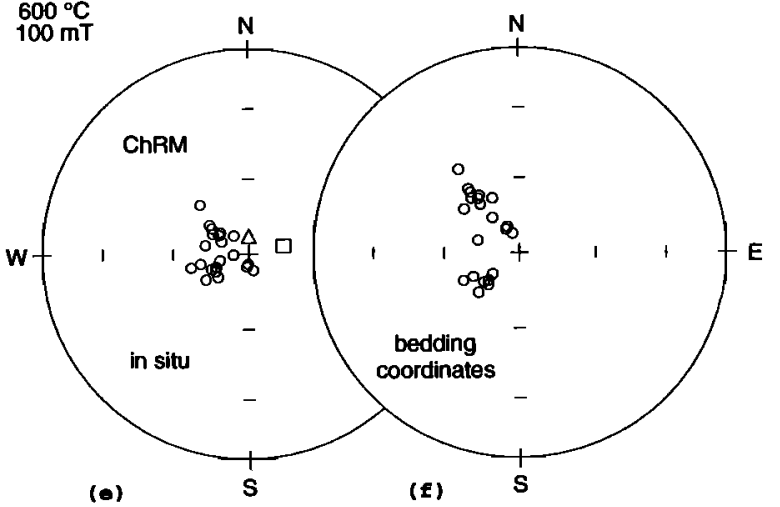

Figure 6. (a-c) Orthogonal plots of demagnetization data from Mount Pearson volcanics; (d) intensity versus sample treatment; (e) equal-area projection of sample ChRM component directions before and (f) after tilt correction. All symbols defined as in Figure 3.

\section{Mount Pearson}

At Mount Pearson, $60 \mathrm{~km} \mathrm{SW}$ of Mount Vance/LeMasurier, thirty-one oriented cores were collected from three sites in a folded volcaniclastic sequence that is intensely silicified, cleaved, and jointed, with epidote needles up to $5 \mathrm{~cm}$ on the joint planes. The NRM intensity is typically strong, of the order of $1 \mathrm{~A} / \mathrm{m}$. Either progressive AF or thermal demagnetization yields well-defined decay trajectories with steep upward directions after the removal of viscous components (Figures $6 \mathrm{a}, 6 \mathrm{~b}, 6 \mathrm{c}$ ). Two of the sites were sampled on one limb of the fold and the third site could only be taken near the hinge of the fold because the remainder of the fold was inaccessible. The site mean directions are significantly better grouped in situ than after returning the limbs to the horizontal $\left(k_{\text {in situ }} / k_{\text {bedding }}=4.7\right)$, indicating that the remanence was most likely acquired after folding. The in situ mean direction ( $\mathrm{dec}=271.1$, inc $=-78.5, a_{95}=12.4$ ) (Table 1) with a relatively large error, deviates from the other
Ruppert Coast volcanics discussed above, as well as from the expected 100 Ma direction [DiVenere et al., 1994]. An oriented hand sample was taken from a dike that intrudes the volcaniclastic sedimentary rocks. The mean direction from three specimens from the dike sample (Table 1) is similar to the expected $100 \mathrm{Ma}$ magnetic field direction for $\mathrm{MBL}$ [DiVenere et al., 1994]. Therefore, if the dike was actually emplaced at around $100 \mathrm{Ma}$, then the metamorphism and deformation observed in the Lower Cretaceous volcanic rocks must have occurred prior to about $100 \mathrm{Ma}$.

\section{Paleomagnetic Results From Hobbs Coast Granodiorites}

\section{Mount Steinfeld}

Thirty-four oriented cores were collected from five sites in a homogeneous granodiorite at Mount Steinfeld, approximately 

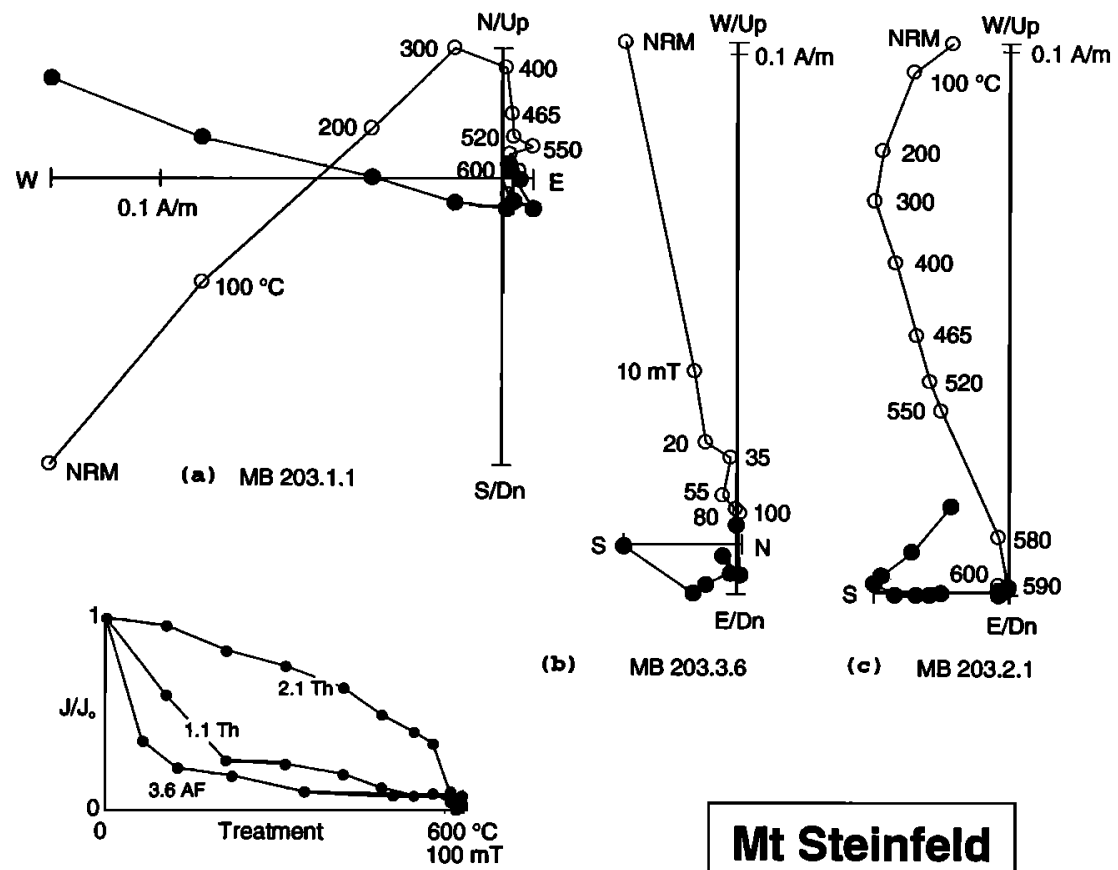

(b)

MB 203.3.6

(c) MB 203.2.1

(a)

\section{Mt Steinfeld Granodiorite}

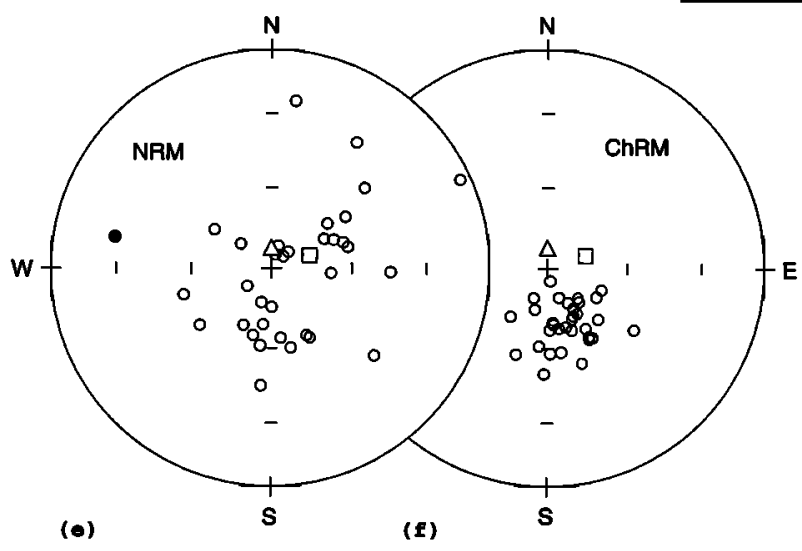

Figure 7. (a-c) Orthogonal plots of demagnetization data from Mount Steinfeld granodiorite; (d) intensity versus sample treatment; (e) equal-area projection of sample NRM directions and (f) ChRM component directions. All symbols defined as in Figure 3.

$70 \mathrm{~km}$ ENE of Mount Matikonis. The NRM directions are fairly scattered (Figure 7e), though all but one sample have negative inclination. Remanent intensities are of the order of $0.1 \mathrm{~A} / \mathrm{m}$. A number of untreated samples were remeasured after 30 months of storage in magnetically shielded space, at which time the remanent intensity had decreased by $30 \%$ to $60 \%$. Comparable viscous magnetizations are removed during low treatment steps of thermal and AF demagnetization yielding a moderate to steep up, south-southeasterly directed characteristic magnetization (Figures 7a, 7b, 7c). Coercivities, unblocking temperatures, and Curie point determinations (Figure 7d) are all consistent with magnetite as the primary remanence-carrying mineral. Although most samples display noisy decay trajectories, the ChRM components calculated from the high treatment portions of the demagnetization data are quite consistent (Figure 7f). The mean direction (dec $=160.3$, inc $=-67.8, a_{95}=4.2$ ) (Table 1) is similar to the tilt-corrected Mount Vance/LeMasurier volcanics result.

\section{Mount Sinha}

Twenty-one oriented cores were collected from three sites in foliated granodiorite at Mount Sinha, $18 \mathrm{~km} \mathrm{NNW}$ of Mount Steinfeld. The NRM directions are scattered (Figure 8e), though all samples but one have negative inclination. Remanent intensities are of the order of $0.1 \mathrm{~A} / \mathrm{m}$. Coercivities, maximum blocking temperatures, Curie temperatures, and IRM acquisition behavior are all consistent with magnetite as the primary remanence carrying mineral. Samples from sites 2 and 3 vary in stability but generally yield moderate to steep negative inclination (normal polarity) and westerly directions of magnetization after removal of low stability components (Figures $8 b, 8 c, 8 f$ ). Most samples from site 1 display largely unstable demagnetization behavior (Figure 8a), though two samples yield a reasonably wellresolved steep negative inclination component of magnetization. The in situ mean direction ( $\mathrm{dec}=269.6$, inc $=$ $-80.5, a_{95}=10.4^{\circ}$ ) (Table 1 ) is different from the Mount 


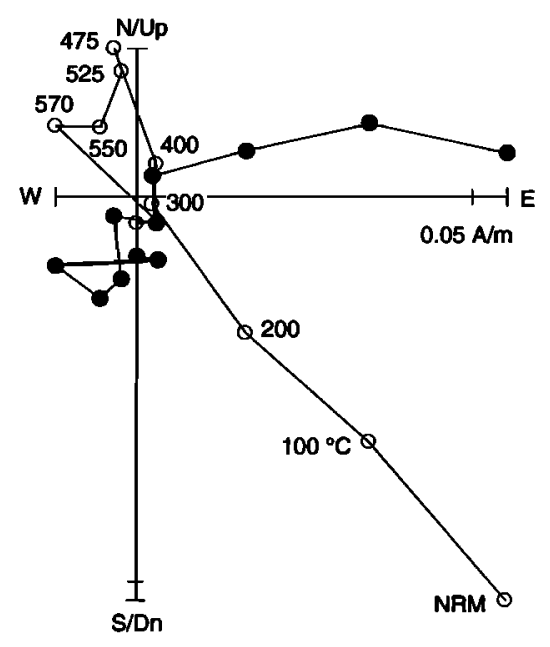

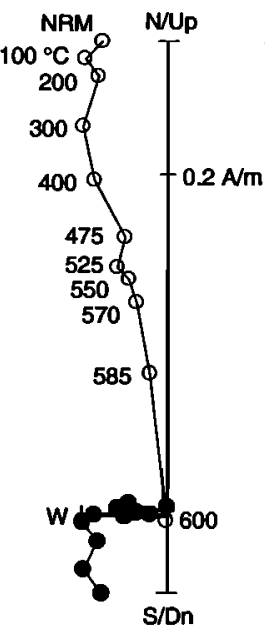

(b)

MB 159.3.2

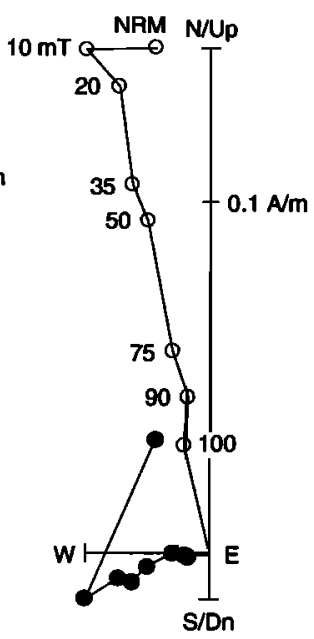

(c) MB 159.3.5

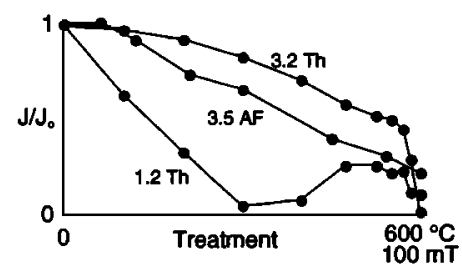

\section{Mt Sinha
Granodiorite}

(a)

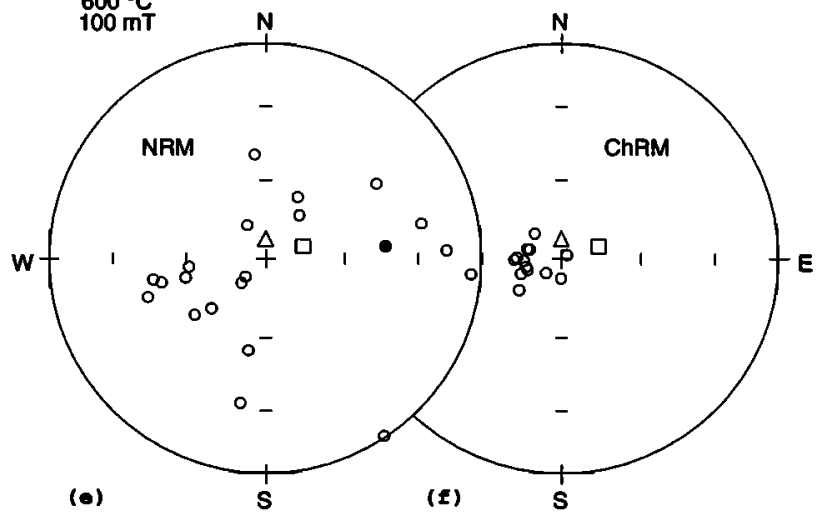

Figure 8. (a-c) Orthogonal plots of demagnetization data from Mount Sinha granodiorite; (d) intensity versus sample treatment; (e) equal-area projection of sample NRM directions and (f) ChRM component directions. All symbols defined as in Figure 3.

Steinfeld granodiorite mean direction, but similar to the mean direction of the metamorphosed volcanics at Mount Pearson.

\section{Early Cretaceous Mean Paleomagnetic Pole}

To assess the tectonic position of MBL during the Early Cretaceous, it is necessary to calculate a representative mean paleopole from the above results for comparison with paleopoles from other continental blocks. This is not completely straightforward, given the complexity of the results from the $\sim 117 \mathrm{Ma}$ units discussed above. Mean poles were calculated for each location by combining the site mean poles. The locality mean poles are widely scattered in situ (Figure 9a). However, we judge the Mount Vance/LeMasurier volcanics results to be the most reliable estimate of the Early Cretaceous pole position. They are supported by a positive contact test with the intruding $\sim 100 \mathrm{Ma}$ syenite, as described above, implying that the magnetization in the volcanics predates the $100 \mathrm{Ma}$ intrusion. The volcanic bedding was used to tilt-correct the $100 \mathrm{Ma}$ syenites which provided a positive regional tilt-test for the $\sim 100 \mathrm{Ma}$ intrusions on the Ruppert/Hobbs Coast [DiVenere et al., 1994], supporting the assumption that the bedding gives a good approximation of the paleohorizontal. The tilt-corrected mean paleomagnetic pole calculated for the $\sim 117 \mathrm{Ma}$ volcanics at Mount Vance/LeMasurier from the six site mean poles is $185.6^{\circ} \mathrm{E} /$ $56.8^{\circ} \mathrm{S}, A_{95}=8.7^{\circ}$ (Figure $9 \mathrm{~b}$, Table 1). Though none of the remaining results may be used unequivocally to estimate the 117 Ma pole position, they give support, as described below, to the Vance/LeMasurier mean pole.

Paleopoles calculated for the results from the higher grade metavolcanics at Wilkins Nunatak, Mount Matikonis, and Mount Pearson are inconsistent, at face value, with the Mount Vance/LeMasurier pole (Figure 9, Table 1). Given the thermal metamorphism, the identified remagnetization at Wilkins Nunatak, and possible structural complications, these results 


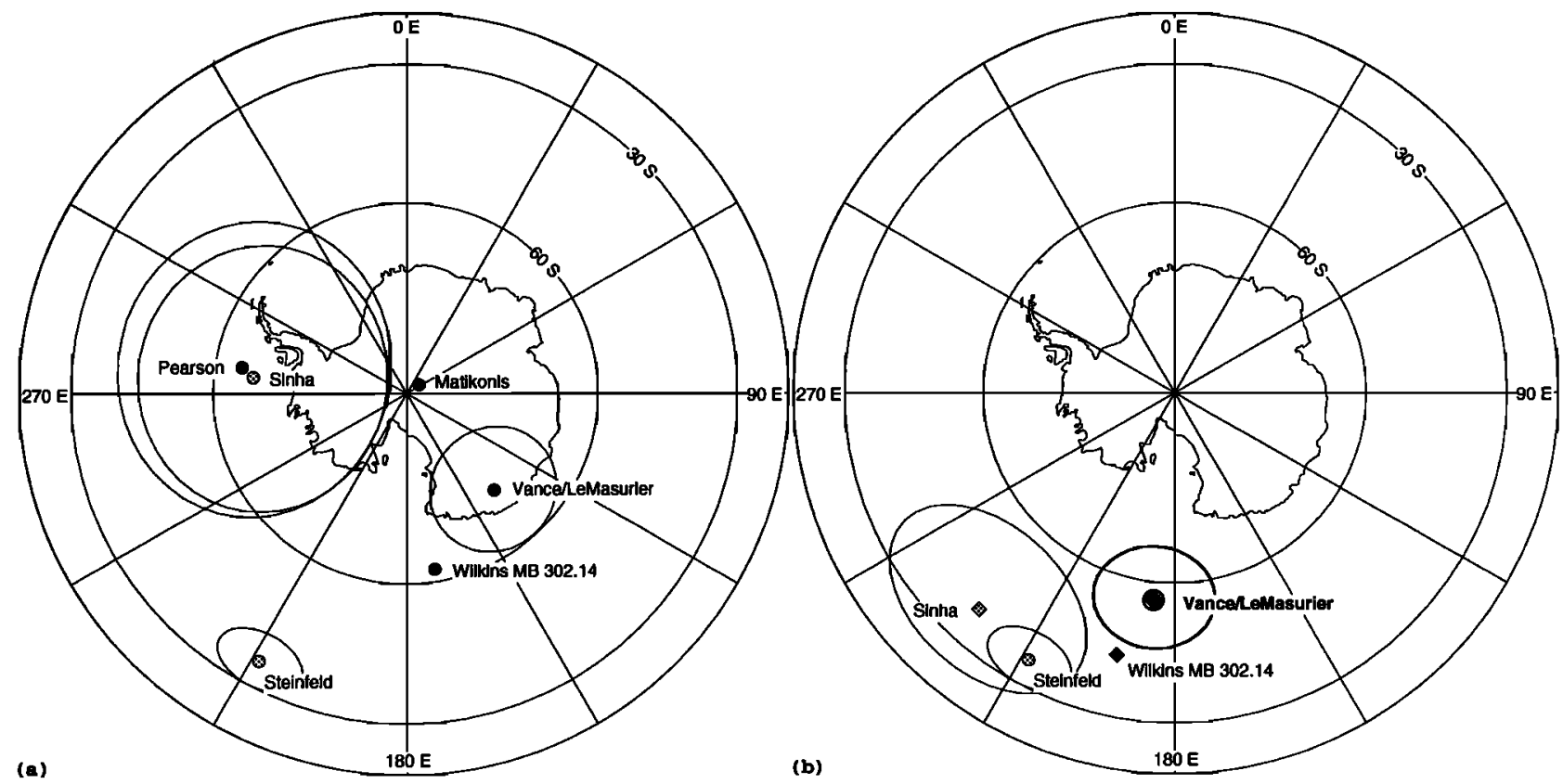

Figure 9. Locality mean paleopoles; (a) all localities in situ, and (b) selected results with tilt corrections applied as discussed in text. Circles are in situ results, diamonds are tilt-corrected results; black symbols are from volcanic units, gray symbols are from granodiorites. Error circles shown are 95\%. This and Figures 10 and 11 are orthographic projections.

appear to be largely remagnetized and/or structurally disturbed, with the possible exception of one site (MB302.14) from Wilkins Nunatak, whose mean pole is offset from the Wilkins $100 \mathrm{Ma}$ granite mean pole in the same sense and amount as the Mount Vance/LeMasurier mean pole is from the 100 Ma Mount Vance syenite. This supports a similar age ( $-117 \mathrm{Ma})$ for the site 14 remanence. If so, this would imply that the antiform at Wilkins Nunatak is a structure pre-dating cooling of the volcanic pile. Based on the mean direction in the $\sim 100 \mathrm{Ma}$ granites, we had inferred that Wilkins Nunatak was tilted, post-100 Ma, about a similar horizontal axis and by a similar amount as Mount Vance/LeMasurier $20 \mathrm{~km}$ to the NNW [DiVenere et al., 1994]. The site 14 in situ result is shown in Figure $9 \mathrm{~b}$ corrected for this tilt.

There is no direct paleohorizontal indicator for the plutonic rocks on the Hobbs Coast. However, the mean paleomagnetic pole from the homogeneous granodiorite at Mount Steinfeld (Figure 9, Table 1) is similar to the tilt-corrected Mount Vance/LeMasurier and Wilkins Nunatak poles (Figure 9b), also being offset to the NNW from the $100 \mathrm{Ma}$ MBL mean pole. On the other hand, the mean pole from the foliated Mount Sinha granodiorite is dissimilar to the Mount Steinfeld result even though the two outcrops are separated by only $18 \mathrm{~km}$ and apparently represent the same igneous unit. The Mount Sinha pole may be brought into agreement with the Mount Steinfeld pole by a rotation about the strike of the foliation (strike/dip $62^{\circ} / 68^{\circ} \mathrm{S}$ ). This may indicate a structural explanation for the difference between the Mount Steinfeld and Mount Sinha poles, probably related to the intrusion of the $\sim 100 \mathrm{Ma}$ syenites at Mount Sinha. For the lack of a better datum, the tilt correction shown for the Mount Sinha pole (Figure 9b, Table 1) is one that brings the foliation to the vertical.

The selected tilt-corrected results from Mount Vance/LeMasurier, Wilkins Nunatak site MB302.14, and Mount Sinha, and the result from Mount Steinfeld (Figure 9b) show a good grouping and pass a regional tilt test at the $99 \%$ confidence interval (with or without Wilkins Nunatak site 14 and Mount Sinha). Assuming that the tilt-corrections for Wilkins Nunatak and Mount Sinha are approximately correct and/or that Mount Steinfeld has not been tilted, this implies that the magnetizations predate the time of tilting, which was inferred to be post-100 Ma [DiVenere et al., 1994] and probably pre-84 Ma at Mount Vance/LeMasurier. The uniform normal polarity magnetizations are consistent with acquisition within the Cretaceous Normal Polarity Superchron (118 to $84 \mathrm{Ma}$ ). A mean pole calculated from the combined Mount Vance/LeMasurier and Mount Steinfeld site means $\left(198.3^{\circ} \mathrm{E} / 48.3^{\circ} \mathrm{S}\right)$ is indistinguishable from a pole based on all four localities. However, given the uncertainties in the tilt-corrections for Mount Sinha and Wilkins Nunatak, and the lack of paleohorizontal control for Mount Steinfeld, we consider the mean pole for the well-supported Mount Vance/LeMasurier volcanics $\left(185.6^{\circ} \mathrm{E} / 56.8^{\circ} \mathrm{S}, A_{95}=8.7^{\circ}\right.$, for $N=6$ sites) (Table 1) to be the best estimate for the $\sim 117 \mathrm{Ma}$ south pole position for at least the Ruppert/Hobbs Coast sampling area of MBL.

\section{Comparison of Paleomagnetic Poles}

The Early and mid-Cretaceous paleomagnetic poles from MBL are compared with poles from TI and AP and the East Antarctic apparent polar wander (APW) path in order to determine relative motions (Figure 10; Table 2). The midCretaceous pole for MBL (MBL 100) [DiVenere et al., 1994] groups well with the $110 \mathrm{Ma}$ pole from TI (TI 110) [Grunow et al., 1991] and a mean pole of similar age calculated for AP (AP 106M) [DiVenere et al., 1994]. These mid-Cretaceous poles are, however, significantly offset from the East Antarctic APW path determined using a global database of paleomagnetic poles transferred into East Antarctic coordinates [DiVenere et 


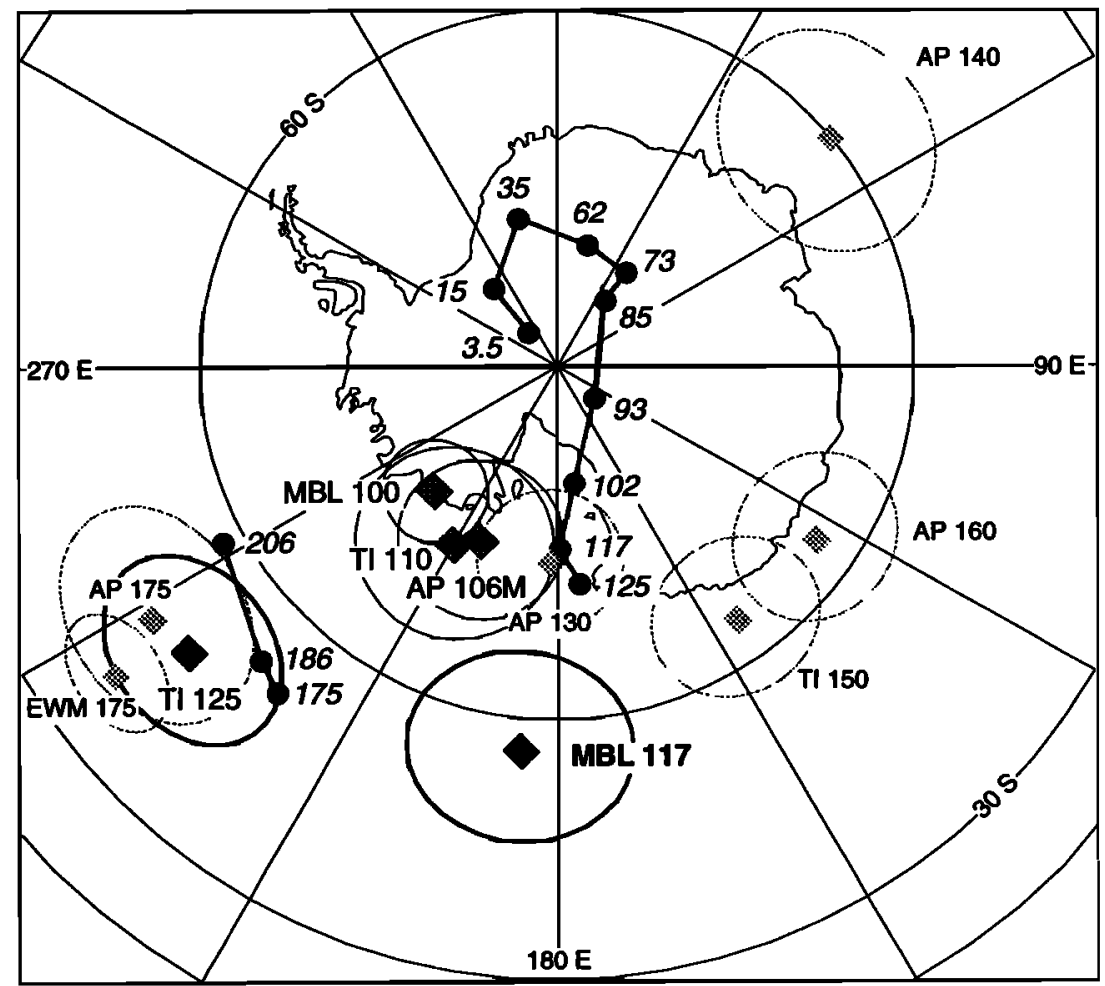

Figure 10. West Antarctic poles with $A_{95}$ circles of confidence (diamonds) (see text and Table 2) plotted with the East Antarctic APW path of DiVenere et al. [1994] (circles).

al., 1994]. From the paleomagnetic comparisons and geologic evidence for Cretaceous and Cenozoic extensional tectonics in the Ross Sea region, we inferred that MBL, TI, and AP have not experienced paleomagnetically resolvable differential motion since about $100 \mathrm{Ma}$, but that there has been significant post-100 Ma motion between these Pacificbordering West Antarctic blocks and the East Antarctic craton, and in particular, that MBL as a whole has been displaced several hundred kilometers from a position closer to Victoria Land as a result of the opening of the Ross Sea [DiVenere et al., 1994].

The new 117 Ma mean pole (MBL 117 in Figure 10), based on the results from the volcanics at Mount Vance/LeMasurier of East MBL (east of the Land Glacier), is significantly different from the 100 Ma MBL pole (MBL 100), with an angular separation of $24 \pm 9^{\circ}$. In contrast, the amount of APW for East Antarctica between about 117 and 102 Ma was only 6 $\pm 5^{\circ}$ (Figure 10 [DiVenere et al., 1994]). Therefore, East MBL must have moved independently of East Antarctica between 117 and $100 \mathrm{Ma}$.

MBL 117 is offset from the $\sim 117$ Ma East Antarctic paleomagnetic pole by $18 \pm 9^{\circ}$. This may be resolved into components of rotation ( $53 \pm 23^{\circ}$ clockwise) and poleward translation (12 $\pm 7^{\circ}$ southward), using the method described by Beck [1989], which represent the accumulated motion (rotation and poleward translation, but not longitudinal motion) of East MBL with respect to East Antarctica since about $117 \mathrm{Ma}$ (actually, with respect to the $117 \mathrm{Ma}$ pole for East Antarctica). Removing the post-100 Ma offset (indeterminate rotation and $11 \pm 6^{\circ}$ northward translation) yields a net poleward translation of $24 \pm 9^{\circ}$ south for East MBL between 117 and $100 \mathrm{Ma}$. Therefore, East MBL moved towards Victoria Land (which was situated near the South Pole) between
117 and $100 \mathrm{Ma}$, but since $100 \mathrm{Ma}, \mathrm{MBL}$ as a whole has moved away from Victoria Land by a smaller amount (i.e., East MBL was farther from Victoria Land at about $117 \mathrm{Ma}$ than it presently is). The implied East MBL-East Antarctica relative motion between 117 and $100 \mathrm{Ma}$ would be even greater if we chose to use the combined MBL $\sim 117 \mathrm{Ma}$ results (including Mount Steinfeld with or without the tilt-corrected Mount Sinha and Wilkins Nunatak site 14).

Cretaceous paleomagnetic results from the Thurston Island (TI) block show a somewhat similar pattern to those from MBL (Figure 10). The difference between the $\sim 125$ Ma pole for TI (TI 125) of Grunow et al. [1987a] and the $\sim 110$ Ma result (TI 110) [Grunow et al., 1991] indicates $26 \pm 11^{\circ}$ of angular change for TI over this $\sim 15$ m.y. time interval, similar to the difference between MBL 117 and MBL 100. We note again that APW for East Antarctica was much smaller $\left(-3^{\circ}\right)$ over the period between 125 and $110 \mathrm{Ma}$. Therefore, as for East MBL, TI moved independently of East Antarctica during the Early Cretaceous.

The large offset between TI 125 and the $\sim 125 \mathrm{Ma}$ pole for East Antarctica [DiVenere et al., 1994] has been discussed by Grunow et al. [1991]. The angular separation between TI 125 and the $\sim 125 \mathrm{Ma}$ pole for East Antarctica is $34 \pm 9^{\circ}$, which resolves into $86 \pm 16^{\circ}$ clockwise rotation and $2 \pm 7^{\circ}$ southward translation, describing the accumulated latitudinal translation and rotational motion of TI with respect to East Antarctica since about $125 \mathrm{Ma}$. Removing the post-110 Ma motion of TI with respect to East Antarctica $\left(26 \pm 26^{\circ}\right.$ clockwise and $6 \pm 7^{\circ}$ northward) yields a net $60 \pm 30^{\circ}$ clockwise rotation and $8 \pm 10^{\circ}$ southward translation of TI between 125 and $110 \mathrm{Ma}$.

The above results from East MBL and TI show that both blocks experienced major tectonic motions with respect to East Antarctica during late Early Cretaceous times. East MBL 
Table 2. Paleomagnetic Poles

\begin{tabular}{|c|c|c|c|c|c|c|}
\hline Block & Age & $N$ & $A_{95}$ & $\operatorname{Lon}^{\circ} \mathrm{E}$ & Lat ${ }^{n} \mathrm{~N}$ & Source \\
\hline MBL & 117 & 6 & 8.7 & 185.6 & -56.8 & this study \\
\hline MBL & 100 & 19 & 3.8 & 224.1 & -75.7 & DiVenere et al. [1994] \\
\hline $\mathrm{TI}$ & 150 & 5 & 7 & 145 & -64 & Grunow et al. [1991] \\
\hline TI & 125 & 5 & 7.9 & 232 & -49 & Grunow et al. [1987a] \\
\hline TI & 110 & 7 & 7.6 & 210 & -73 & Grunow et al. [1991] \\
\hline AP & 175 & $4^{a}$ & 9.5 & 238 & -48 & Longshaw and Griffiths [1983] \\
\hline AP & 160 & 10 & 7.1 & 124 & -64 & Grunow [1993] \\
\hline AP & 140 & 4 & 9.5 & 50 & -60 & Grunow [1993] \\
\hline $\mathrm{AP}$ & 130 & 6 & 5.9 & 182 & -74 & Grunow [1993] \\
\hline $\mathrm{AP}$ & $106 \mathrm{M}$ & 29 & 6.2 & 203.8 & -74.3 & $\begin{array}{l}\text { calculated in DiVenere et al. [1994] } \\
\text { from site means of Kellogg [1980], } \\
\text { Kellogg and Rowley [1989], and } \\
\text { Grunow [1993] }\end{array}$ \\
\hline EWM & 175 & 8 & 5.3 & 235.2 & -41.2 & Grunow et al. $[1987 \mathrm{~b}]$ \\
\hline $\mathrm{NZ}$ & 207 & 24 & $10.6^{b}$ & 162 & -24 & $\begin{array}{l}\text { Grindley et al. }[1981] \text { with updated age } \\
\text { from Graham et al. } \text { [1993] }\end{array}$ \\
\hline EAnt & 102 & $6^{c}$ & 4.2 & 171.8 & -80.3 & DiVenere et al. [1994] \\
\hline EAnt & 117 & $4^{c}$ & 2.9 & 179.2 & -74.9 & DiVenere et al. [1994] \\
\hline EAnt & 125 & $6^{c}$ & 3.5 & 173.9 & -71.9 & DiVenere et al. [1994] \\
\hline EAnt & 175 & $17^{c}$ & 4.4 & 220.4 & -52.7 & Kellogg [1988] \\
\hline EAnt & 186 & $3^{d}$ & 11.0 & 225.3 & -54.3 & Van der Voo $[1993]^{e f f}$ \\
\hline EAnt & 206 & $4^{d}$ & 7.0 & 242.4 & -58.0 & Van der Voo $[1993]^{f, g}$ \\
\hline
\end{tabular}

MBL, Marie Byrd Land; TI, Thurston Island; AP, Antarctic Peninsula; EWM, Ellsworth-Whitmore Mountains; EAnt, East Antarctica; NZ, New Zealand; Lon and Lat are mean paleomagnetic pole east longitude and north latitude (negative is south latitude); $N$ is number of sites used to calculate mean; $A_{95}$ is the radius of the $95 \%$ cone of confidence about the mean pole.

a $\quad N=4$ group means from 24 site means.

${ }^{b} \quad A_{95}$ conservatively estimated as the major axis of the confidence ellipse.

$c \quad$ Number of studies.

d Number of continent mean poles.

e $\quad \mathrm{Jl}$ mean pole, $260^{\circ} \mathrm{E} / 70^{\circ} \mathrm{N}$ in northwest African coordinates.

$f$ Gondwana mean poles rotated to East Antarctic reference frame using euler pole consistent with Van der Voo [1993] plate model (-12.36/-33.81/-53.29).

$8 \mathrm{Tru} / \mathrm{Jl}$ mean pole, $230^{\circ} \mathrm{E} / 70^{\circ} \mathrm{N}$ in northwest African coordinates.

experienced a large $\left(-24^{\circ}\right)$ southward translation towards Victoria Land between 117 and $100 \mathrm{Ma}$. The Early Cretaceous pole from TI is offset in the same sense, but the amount is not statistically significant $\left(8^{\circ} \pm 10^{\circ}\right)$. Unfortunately, East MBL's 117 to $100 \mathrm{Ma}$ rotation can not be separated from its $100 \mathrm{Ma}$ to Recent rotation because the 100 Ma pole (MBL 100) lies directly over MBL itself. Nevertheless, both East MBL and TI have experienced large $\left(-53^{\circ}\right.$ and $86^{\circ}$, respectively) cumulative clockwise rotation with respect to East Antarctica since the Early Cretaceous, and a large $\left(\sim 60^{\circ}\right)$ clockwise rotation characterizes the motion of TI with respect to East Antarctica from 125 to $110 \mathrm{Ma}$. In summary, the motion of East MBL with respect to East Antarctica contains a large component of latitudinal translation while that for TI is dominantly a rotation during late Early Cretaceous times; any longitudinal components of motion cannot be determined from the paleomagnetic data but must be constrained by indirect geological arguments.

There are no Cretaceous or younger rocks in the EllsworthWhitmore Mountains block (EWM). The 175 Ma pole of Grunow et al. [1987b] (EWM 175) is similar to but significantly offset from the well-constrained 175 Ma pole for
East Antarctica (EAnt 175) [Kellogg, 1988]. The angular difference between EWM 175 and EAnt 175 is $15 \pm 7^{\circ}$, which decomposes into $19 \pm 9^{\circ}$ clockwise rotation and $10^{\circ} \pm 6^{\circ}$ southward translation for the total motion of EWM with respect to East Antarctica (EAnt 175) since $175 \mathrm{Ma}$. Based on geological evidence and paleomagnetic results from Cambrian sedimentary strata [Watts and Bramall, 1981; Grunow et al., 1987b] and Middle Jurassic igneous rocks (EWM 175), Dalziel and Grunow [1992] concluded that EWM had been displaced from an original position within Gondwana between the Pensacola Mountains of East Antarctica and the Cape Mountains of South Africa, and had experienced a $\sim 90^{\circ}$ counterclockwise rotation, following Permo-Triassic folding but prior to the Middle Jurassic.

DiVenere et al. [1994] reviewed the mid-Cretaceous paleomagnetic results available from the Antarctic Peninsula (AP) and calculated a $\sim 106 \mathrm{Ma}$ mean pole from the combined northern AP results of Grunow [1993] and southern AP results of Kellogg and Rowley [1989]. This pole (AP 106M in Figure 10) is consistent with the 100 to $110 \mathrm{Ma}$ results from MBL and TI, implying that AP has not experienced significant post$100 \mathrm{Ma}$ relative motion with respect to MBL and TI. Like 
MBL 100 and TI 110, AP 106M is offset from the East Antarctic APW path, implying a small but significant post$100 \mathrm{Ma}$ motion with respect to the craton.

The Middle Jurassic pole for AP (AP 175) [Longshaw and Griffiths, 1983] is consistent with EWM 175 and similarly implies a moderate $\left(20 \pm 14^{\circ}\right.$ clockwise) rotation of AP with respect to East Antarctica since about $175 \mathrm{Ma}$, some of which is accounted for by post $\sim 100 \mathrm{Ma}$ motions [DiVenere et al., 1994]. Accordingly, Grunow et al. [1987b] suggested that EWM and AP have moved as a single block since about 175 $\mathrm{Ma}$ and together rotated with respect to East Antarctica, due to the opening of the Weddell Sea.

Paleomagnetic data for the period between about 175 and $110 \mathrm{Ma}$ present a less coherent picture for the motion of AP during this time. Grunow's [1993] Late Jurassic and Early Cretaceous AP results (AP 160 and AP 140) show very large offsets from the East Antarctic APW path, implying that AP experienced a major clockwise rotation with respect to East Antarctica between $175 \mathrm{Ma}$ and $160 / 140 \mathrm{Ma}$, which she considered to be the result of opening of a wide Weddell Sea as a result of Gondwana breakup. This was apparently followed by a large counterclockwise rotation of AP into its present position (with respect to East Antarctica) by $130 \mathrm{Ma}$, based on the $130 \mathrm{Ma}$ pole (AP 130) of Grunow [1993]. This counterclockwise rotation was proposed to have resulted in the subduction of as much as $1000 \mathrm{~km}$ of Jurassic Weddell seafloor beneath southeastern AP, giving rise to the Early Cretaceous Palmer Land deformation event in the southern AP [Kellogg and Rowley, 1989]. Although these rotations are lent some credence by the similarity of AP 160 with the Late Jurassic pole from TI (TI 150) [Grunow et al., 1991], which also implies a major clockwise rotation of TI (with respect to East Antarctica) between about 150 and $125 \mathrm{Ma}$, the complicated sequence of large AP rotations implied at face value by the 160,140 , and $130 \mathrm{Ma}$ poles belies the simple pattern represented by the bracketing 175 and $106 \mathrm{Ma}$ poles. We suggest that the 160 and 140 Ma results (which do not agree well with one another) may represent localized block rotations. Alternatively, the northernmost AP, north of $64^{\circ} \mathrm{S}$, could have rotated independently of the remainder of AP south of $66^{\circ} \mathrm{S}$ between about 160 and $106 \mathrm{Ma}$. Otherwise, a fortuitous combination of rotations is needed for all AP to account for the agreement of AP 175 with EWM 175.

There are also problems with the suggestion that AP was in its present position with respect to East Antarctica by $130 \mathrm{Ma}$ [Grunow, 1993]. Three of the six sites that make up the 130 Ma pole of Grunow [1993] are from an apparently remagnetized siltstone unit. Also, the $130 \mathrm{Ma}$ results are of uniform normal polarity and fall in the vicinity of the $\sim 106$ Ma mean pole for AP, suggesting the possibility of partial or complete remagnetization as a result of the widespread midCretaceous intrusive event, during which time the field was of normal polarity. Therefore, we propose that the existing paleomagnetic data show that AP was in its present position with respect to $\mathrm{MBL}$ and $\mathrm{TI}$, and near its present position with respect to East Antarctica, by about $106 \mathrm{Ma}$ and not necessarily before.

More work clearly needs to be done to clarify the Late Jurassic through Early Cretaceous motions of AP. The arguments presented above suggest that the motions of AP, or at least that part south of $66^{\circ} \mathrm{S}$, may be described by the relatively simple motions implied by AP 175 and AP 106M, without a major rotation during the Late Jurassic and Early
Cretaceous. This would imply a different cause for the Palmer Land deformation event in the southern AP than that proposed by Grunow [1993].

\section{Tectonic Reconstruction of West Antarctica}

Prior to rifting at about $100 \mathrm{Ma}$ and final separation by about $85 \mathrm{Ma}$, New Zealand (including the Chatham Rise and Campbell Plateau) was adjacent to MBL [Mayes et al., 1990]. Given the complementary convergent margin tectonic associations of Mesozoic calc-alkaline rocks in East MBL and the Mesozoic arc, forearc, and accretionary complex rocks of the Eastern Province of New Zealand, it is reasonable assumption that East MBL and the Eastern Province of New Zealand may have shared a common history.

The geology of West MBL (approximately west of the Land Glacier), which contains the Swanson Formation turbidites and Ford Granodiorite, is linked to the Robertson Bay and Bowers terranes of North Victoria Land and the Western Province of New Zealand. Both North Victoria Land and the Western Province of New Zealand contain likely equivalent lower Paleozoic turbidites and Devonian granodiorite. North Victoria Land, with the western provinces of New Zealand and MBL, are thought to have accreted to East Antarctica during the late Paleozoic [Weaver et al., 1991; Borg and DePaolo, 1991]. There is, however, no clear relationship between the Eastern and Western Provinces of New Zealand across the Median Tectonic Zone [Bradshaw, 1989, 1993; Kimbrough et al., 1993] (Figure 1).

The Permian through Lower Cretaceous arc, forearc, and accretionary complex rocks of the Eastern Province of New Zealand were formed on the convergent margin of the south Pacific rim of Gondwana, which included New Zealand, the Antarctic Peninsula and Scotia Arc, and southern South America [Dalziel and Grunow, 1985; Dalziel and Forsythe, 1985; Bradshaw, 1989; Tranter 1991]. Previous reconstructions (based on the Paleozoic geologic relations) had maintained all of MBL and New Zealand in a position adjacent to North Victoria Land similar to their midCretaceous, pre-breakup position. This position leaves a large gap between the forearc sequences of New Zealand and AP, though models have been put forward to account for the gap (e.g., Figure 2 in Dalziel and Grunow, 1992).

Given the geologically reasonable assumption that East MBL was part of the Pacific convergent margin of Gondwana, comparison of the new 117 Ma pole with the East Antarctic APW path implies that East MBL was of the order of $1000 \mathrm{~km}$ more distant from North Victoria Land in the Early Cretaceous than it presently is. Based on this, we propose an Early Cretaceous reconstruction (Figure 11a) in which East MBL and the Eastern Province of New Zealand are placed adjacent to the Weddellia crustal blocks (AP, TI, and EWM). The western provinces of MBL and New Zealand are maintained in their presumed Devonian through mid-Cretaceous position adjacent to North Victoria Land. As a first order approximation, the Chatham Rise and Campbell Plateau are held rigidly to East MBL in their mid-Cretaceous, preseparation configuration. We have removed the Cenozoic deformation along the Alpine Fault from the Eastern Province of New Zealand. The present outlines of the West Antarctic crustal blocks (see Figure 1) are used in the reconstruction. The area within the West Antarctic continental outline, but between the presumed rigid West Antarctic blocks (Figures 1, 11a, and 11b), is assumed to be 
a

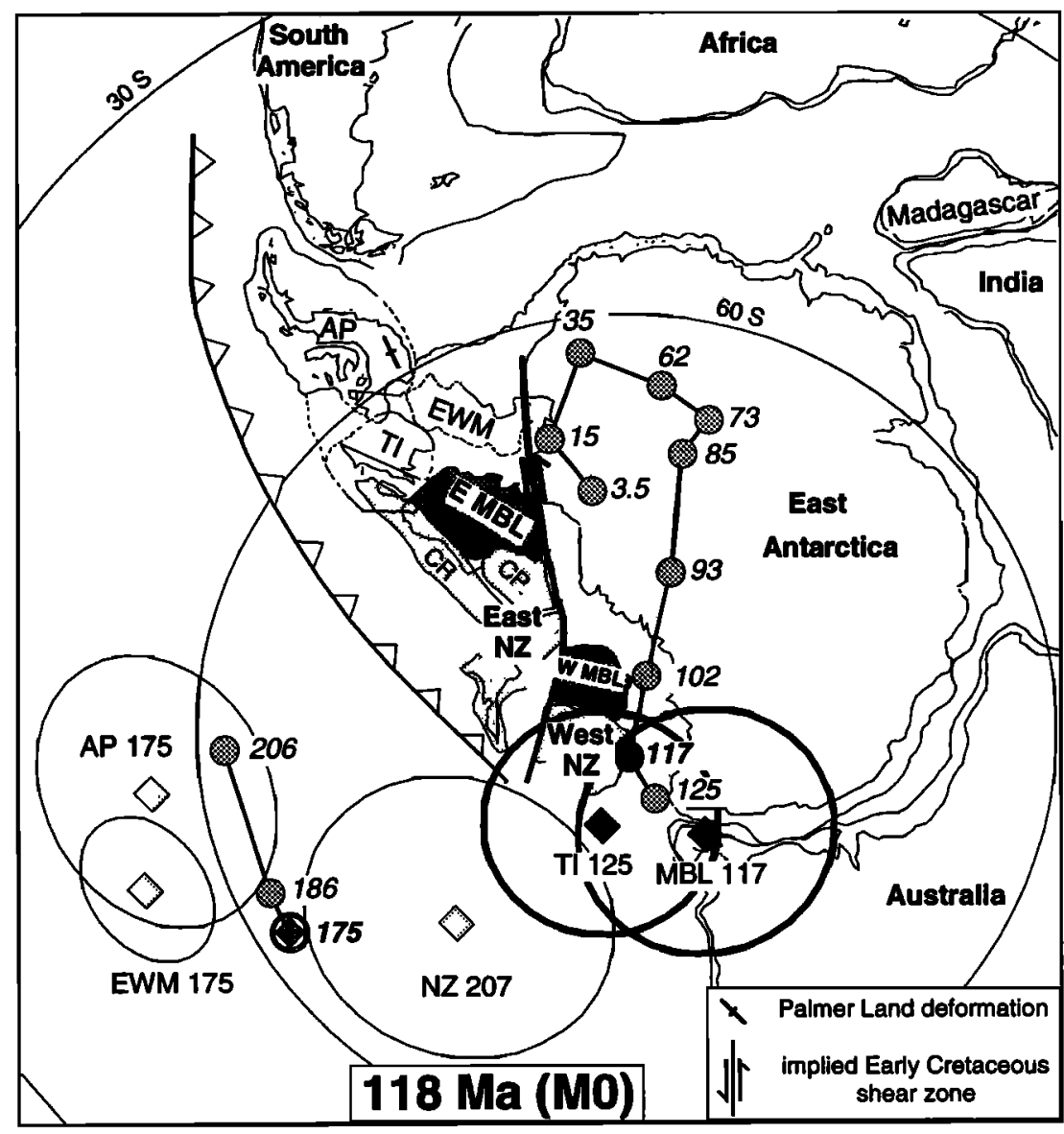

b

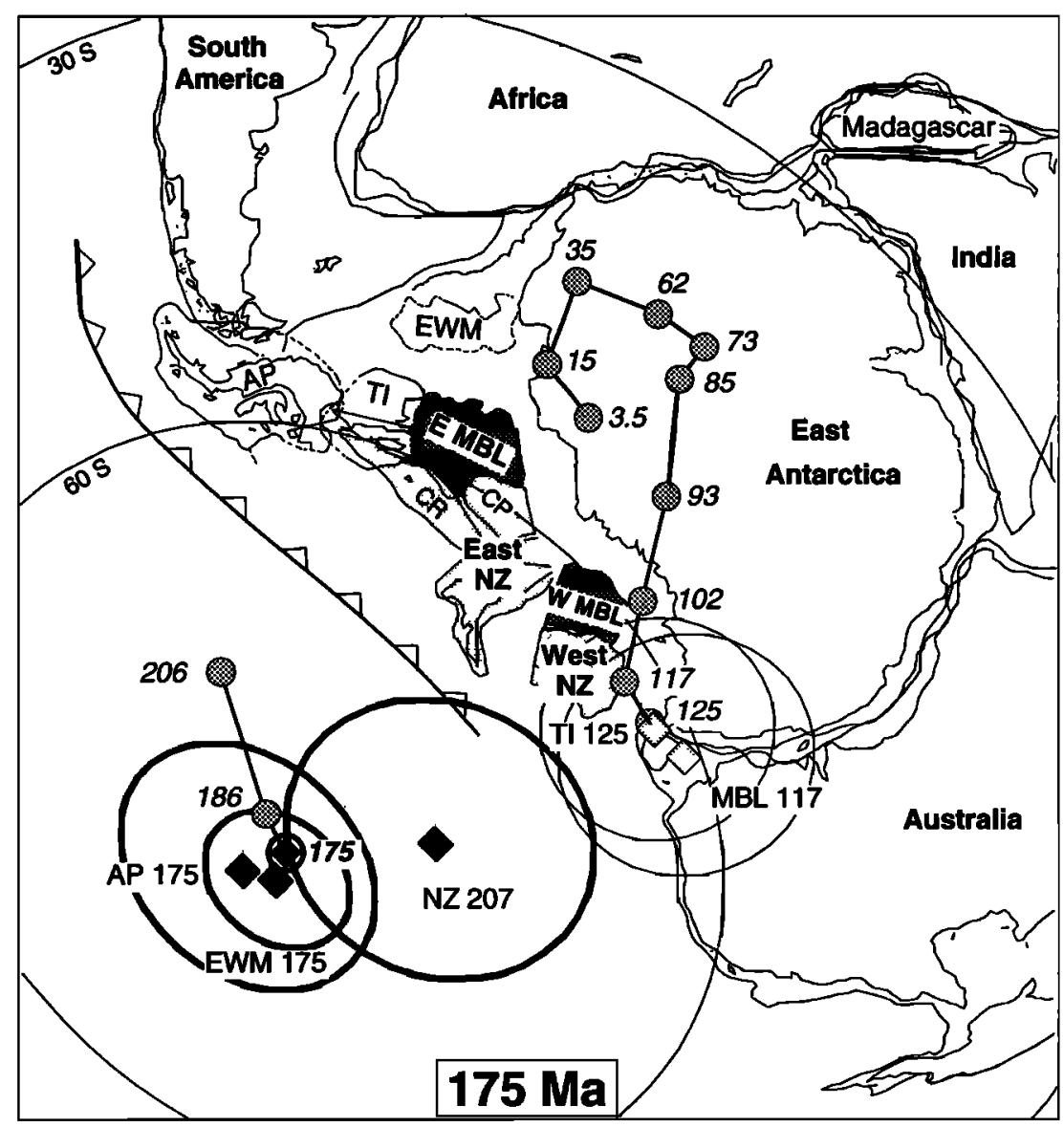


continental crust that has behaved in a nonrigid manner (in a gross sense) between the time of Gondwana breakup and the present. Our reconstruction reconciles the Early Cretaceous poles from East MBL and TI with the East Antarctic APW path while maintaining the coherence of the belt of Permian igneous rocks found in East MBL and in TI, and places the Eastern Province of New Zealand along a continuous convergent margin (Figure 11a). The reconstruction is similar to the Early Cretaceous model of Grunow [1993] for West Antarctica, but implies a somewhat larger amount of displacement for TI (as is in fact indicated by the TI 125 pole) and, significantly, now includes East MBL and the Eastern Province of New Zealand within Weddellia.

Relatively little adjustment of Weddellia is required in the Early Cretaceous reconstruction to produce a $175 \mathrm{Ma}$ (preGondwana breakup) reconstruction (Figure 11b), though AP must be moved to avoid overlap with South America. The rotation of AP shown in the reconstructions is in keeping with the clockwise rotation of the Andean magmatic arc required by the initial opening of the Rocas Verdes basin in southern South America and the Weddell Sea basin in the Late Jurassic and Early Cretaceous [Barker et al., 1991]. The $175 \mathrm{Ma}$ reconstruction (Figure 11b) satisfies the Middle Jurassic poles from AP and EWM, and interestingly, the Early Cretaceous poles from MBL and TI with respect to the East Antarctic APW path. The pre-breakup configuration maintains the continuity of the forearc and accretion complexes of South America, AP, and the Eastern Province of New Zealand.

Further support for these reconstructions comes from paleomagnetic data from New Zealand. If all of New Zealand is kept in its prerift, $\sim 100$ Ma position with respect to East Antarctica [DiVenere et al., 1994], then the earliest Jurassic paleopole from the Murihiku Terrane of the Eastern Province of New Zealand (NZ 207, Figure 11b) (paleomagnetic results of Grindley et al. [1981]; revised age of Graham et al. [1993]) does not agree with the East Antarctic APW path, as noted by Grindley et al. [1981]. The New Zealand pole implies that at least the Murihiku Terrane was at a lower paleolatitude than would be the case given a mid-Cretaceous, predrift position for New Zealand [e.g., DiVenere et al., 1994]. In the preGondwana breakup reconstruction (Figure 11b), NZ 207 is offset from the East Antarctic APW path, but now the position of East New Zealand is consistent with the paleolatitude implied by the pole. We assumed for the reconstruction (Figures 11a and 11b) that East MBL and Eastern Province of New Zealand comprised a single block until New Zealand separated from Antarctica by about $85 \mathrm{Ma}$. The New Zealand pole may be more fully reconciled with the East Antarctic APW path if East MBL and the Eastern Province of New Zealand, together or individually, are allowed a small to moderate counterclockwise vertical axis rotation between the Jurassic and Early Cretaceous. It can be seen therefore that while MBL
117 implies that East MBL and the Eastern Province of New Zealand were part of Weddellia as late as about $117 \mathrm{Ma}$, it may be inferred from NZ 207 that this general crustal configuration had existed as early as the earliest Jurassic.

Following Gondwana breakup, the Weddellia blocks were displaced as a result of changing plate kinematics between Antarctica, South America, and Africa. A simple model would have AP moving northward with South America between the Middle Jurassic and the Early Cretaceous. Regardless of whether or not significant rotations of the Weddellia blocks occurred between 175 and 125 Ma [Grunow et al., 1991; Grunow 1993], the new $117 \mathrm{Ma}$ pole from MBL requires that East MBL, TI, and EWM were not displaced towards their midCretaceous positions [DiVenere et al., 1994] until after 117 Ma (Figure 11a).

Marine geophysical evidence for the age of oldest oceanic lithosphere in the Weddell Sea is equivocal, with estimated ages ranging from around 160-156 Ma (M29 to M25; [LaBrecque and Barker, 1981; LaBrecque, 1986]) to as young as about $130 \mathrm{Ma}(\mathrm{MlO})$ as indirectly inferred from the spreading history in the southwest Indian Ocean [Martin and Hartnady, 1986]. Ophiolitic remnants of the Rocas Verdes basin floor are dated as old as $150 \mathrm{Ma}$ [Mukasa et al., 1988]. Nevertheless, our model and previous paleomagnetically controlled tectonic models indicate that major rotations of the Weddellia blocks postdate these estimates for initial opening of the Weddell Sea. If the interpretations of the marine geophysical and paleomagnetic data are both correct, then the major movements of Weddellia may be linked to a plate reorganization during the Cretaceous Quiet interval which is difficult to map due to the expected absence of magnetic lineations.

Grunow [1993] related the Palmer Land deformation event in the southern AP, in which Middle and Upper Jurassic volcanic and sedimentary rocks were folded and thrusted prior to the emplacement of the Lassiter Coast intrusive suite, to the subduction of ocean crust, first created and then destroyed by the proposed large clockwise and ensuing counterclockwise rotations of AP and TI during the Late Jurassic and Early Cretaceous. The Lassiter Coast intrusions were emplaced largely between about 110 and $96 \mathrm{Ma}$ [Kellogg and Rowley, 1989], though one unit has been dated at $128 \mathrm{Ma}$ [Pankhurst and Rowley, 1991]. In any prebreakup reconstruction that satisfies the Middle Jurassic pole from AP while reserving space for the rest of Weddellia (which now includes MBL and the Eastern Province of New Zealand), northern AP must be placed outboard of southern South America to avoid overlap with South America. The Antarctic Peninsula must then move northeasterly with South America towards East Antarctica while rotating clockwise between breakup and the midCretaceous, by which time it is expected to be nearer to its present position with respect to East Antarctica [DiVenere et

Figure 11. Reconstruction of the West Antarctic and New Zealand crustal blocks within Gondwana (East Antarctica fixed) for (a) $118 \mathrm{Ma}$ (anomaly M0) and (b) $\sim 175 \mathrm{Ma}$. Diamonds are paleomagnetic poles from West Antarctic blocks and New Zealand with $A_{95}$ circles of confidence (Table 2) shown in reconstructed positions. Connected gray circles are the East Antarctic APW path: Cretaceous through Cenozoic path is from DiVenere et al. [1994]; 175 Ma pole is from Kellogg [1988]; 186 and 206 Ma poles are Gondwana mean poles of Van der Voo [1993] transferred into the East Antarctic reference frame. Crustal blocks: AP, Antarctic Peninsula; TI, Thurston Island; EWM, Ellsworth Whitmore Mountains; E MBL and W MBL, East and West Marie Byrd Land; NZ, New Zealand; CR, Chatham Rise; CP, Campbell Plateau. 
al., 1994]. The Palmer Land deformation may therefore have been caused by collision with EWM (which is now constrained by the new Early Cretaceous result from MBL to lie inboard of AP until after $117 \mathrm{Ma}$ ) or by compression of the intervening "nonrigid" crust that may have lain between AP and EWM. Alternatively, the Palmer Land deformation may have been caused by AP overriding the early formed Weddell Sea crust formed as a result of the motion of South America away from Weddellia during the Late Jurassic and Early Cretaceous. A large amount of subduction beneath the Weddell Sea side of AP is in any event not particularly appealing since it would mean two-sided subduction about a relatively narrow strip of continent.

The displacements of the Weddellia blocks eventually resulted in the suturing of East and West MBL and the Eastern and Western provinces of New Zealand. The timing of the implied suturing (between about 117 and $100 \mathrm{Ma}$ ) is approximately coeval with the last phase of the Rangitata II Orogeny in New Zealand [Bradshaw, 1989]. Though Bradshaw [1989] proposed that this deformation might have been caused by the approach and subduction of the Phoenix/Pacific Ridge, the motions inferred from the MBL and New Zealand paleomagnetic results suggest that the Eastern ProvinceWestern Province amalgamation may have been at least partly responsible.

Acknowledgments. These results are from samples collected during the tripartite, United States-United Kingdom-New Zealand, 1990-1991 South Pacific Rim International Tectonics Expedition (SPRITE). We thank SPRITE members Sam Mukasa and Dave Palais of the University of Michigan, Bob Pankhurst and Bryan Storey of the British Antarctic Survey (BAS), and John Bradshaw and Steve Weaver of the University of Canterbury for their contributions to this research and permission to use their unpublished data. We also thank mountaineers Pete Cleary and Andy Harris of the New Zealand Antarctic Research Program (NZARP; now NZAP) and Damo Carroll of BAS for their expert guiding in the field and assistance in sample collection; Twin Otter pilot Paul Robertson and air mechanic Alan Hopkins of BAS for safely delivering us to distant outcrops; U.S. Navy Antarctic Development Squadron VXE6 for LC-130 support; the U.S. Office of Polar Programs and Antarctic Support Associates for logistical support; and NZARP and the personnel of Scott Base for field support and base accommodations. We thank Lisa Gahagan of the PLATES project at the Institute for Geophysics, University of Texas at Austin for help with the Antarctic reconstruction in Figure 12. This paper was improved with the help of thoughtful reviews by Myrl Beck, Karl Kellogg, and Rob Van der Voo. This research was supported by NSF Office of Polar Programs grants DPP 8916470 (D.V.K.) and DPP 8917127 (I.W.D.D.). Lamont-Doherty Earth Observatory contribution 5335. University of Texas, Institute for Geophysics contribution 1142 .

\section{References}

Adams, C. J., Geochronological studies of the Swanson Formation of Marie Byrd Land, West Antarctica and correlation with northern Victoria Land, East Antarctica, and South Island, New Zealand, $N . Z$. J. Geol. Geophys., 29, 345-358, 1986.

Adams, C. J., Geochronology of granite terranes in the Ford Ranges, Marie Byrd Land, West Antarctica, N. Z. J. Geol. Geophys., 30, 51$72,1987$.

Ade-Hall, J. M., H. C. Palmer, and T. P. Hubbard, The magnetic and opaque petrological response of basalts to regional hydrothermal alteration, Geophys. J. R. Astron. Soc., 24, 137-174, 1971.

Barker, P. F., and M. J. Lonsdale, A multichannel seismic profile across the Weddell Sea margin of the Antarctic Peninsula: Regional tectonic implications, in Geological Evolution of Antarctica, M. R. A.
Thomson, J. A. Crame, and J. W. Thornson, pp. 237-241, Cambridge University Press, New York, 1991.

Barker, P. F., I. W. D. Dalziel, and B. C. Storey, Tectonic development of the Scotia Arc region, in The Geology of Antarctica, edited by R. J. Tingey, pp. 215-248, Clarendon, Oxford, 1991.

Beck, M. E., Jr., Paleomagnetism of continental North America: Implications for displacement of crustal blocks within the Western Cordillera, Baja California to British Columbia, in Geophysical Framework of the Continental United States, edited by L. C. Pakiser and W. D. Mooney, Mem. Geol. Soc. Am. 172, 1989.

Borg, S. G., and D. J. DePaolo, A tectonic model of the Antarctic Gondwana margin with implications for southeastern Australia: Isotopic and geochemical evidence, Tectonophysics, 196, 339-358, 1991.

Bradshaw, J. D., Cretaceous geotectonic patterns in the New Zealand region, Tectonics, 8, 803-820, 1989.

Bradshaw, J. D., A review of the Median Tectonic Zone: Terrane boundaries and terrane amalgamation near the Median Tectonic Line, N.Z. J. Geol. Geophys., 36, 117-125, 1993.

Bradshaw, J. D., P. B. Andrews, and B. D. Field, Swanson Formation and related rocks of Marie Byrd Land and a comparison with the Robertson Bay Group of northern Victoria Land, in Antarctic Earth Science, edited by R. L. Oliver, P. R. James, and J. B. Jago, pp. 274279, Australian Academy of Science, Canberra, 1983.

Cooper, A. K., F. J. Davey, and K. Hinz, Crustal extension and origin of sedimentary basins beneath the Ross Sea and Ross Ice Shelf, Antarctica, in Geological Evolution of Antarctica, M. R. A. Thomson, J. A. Crame, and J. W. Thomson, pp. 285-291, Cambridge University Press, New York, 1991.

Dalziel, I. W. D., and D. H. Elliot, West Antarctica: Problem child of Gondwanaland, Tectonics, 1, 3-19, 1982.

Dalziel, I. W. D., and R. D. Forsythe, Andean evolution and the terrane concept, in Tectonostratigraphic Terranes of the Circum-Pacific Region, Earth Sci. Ser. 1, edited by D. G. Howell, pp. 565-581, Circum-Pacific Council for Energy and Mineral Resources, Houston, Tex., 1985.

Dalziel, I. W. D., and A. M. Grunow, The Pacific margin of Antarctica: terranes within terranes within terranes, in Tectonostratigraphic Terranes of the Circum-Pacific Region, Earth Sci. Ser. 1, edited by D. G. Howell, pp. 555-564, Circum-Pacific Council for Energy and Mineral Resources, Houston, Tex., 1985.

Dalziel, I. W. D., and A. M. Grunow, Late Gondwanide tectonic rotations within Gondwanaland, Tectonics, 11, 603-606, 1992.

DiVenere, V. J., D. V. Kent, and I. W. D. Dalziel, Mid-Cretaceous paleomagnetic results from Marie Byrd Land, West Antarctica: A test of post-100 Ma relative motion between East and West Antarctica, J. Geophys. Res., 99, 15,115-15,139, 1994.

Fisher, R. A., Dispersion on a sphere, Proc. R. Soc. London A, 217, 295305, 1953.

Graham, I. J., D. S. Coombs, and N. D. J. Cook, Effects of lowtemperature alteration on the $\mathrm{Rb}-\mathrm{Sr}$ age of andesitic igneous rocks: Park Volcanics Group, Southland, New Zealand, Chem. Geol., 104, 281-292, 1993.

Grindley, G. W., and F. J. Davey, The reconstruction of New Zealand, Australia, and Antarctica, in Antarctic Geoscience, edited by C. Craddock, pp. 15-29, University of Wisconsin Press, Madison, 1982.

Grindley, G. W., P.J. Oliver, and J. C. Sukroo, Lower Mesozoic position of southern New Zealand determined from paleomagnetism of the Glenham Porphyry, Murihiku Terrane, Eastern Southland, in Gondwana Five, edited by M. M. Cresswell and P. Vella, pp. 319326, A. A. Balkerna, Rotterdam, 1981.

Grunow, A.M., Paleomagnetic data from the Antarctic Peninsula and their implication for opening of the Weddell Sea, J. Geophys. Res., 98, 13,815-13,833, 1993.

Grunow, A.M., D. V. Kent, and I.W.D. Dalziel, Mesozoic evolution of West Antarctica and Weddell Sea Basin: New paleomagnetic constraints, Earth and Planet. Sci. Lett., 86, 16-26, 1987a.

Grunow, A.M., I.W.D. Dalziel, and D. V. Kent, Ellsworth-Whitmore Mountains crustal block, western Antarctica: New paleomagnetic 
results and their tectonic significance, in Gondwana Six: Structure, Tectonics, and Geophysics, Geophys. Monogr. Ser., vol. 40, edited by G. D. McKenzie, pp. 161-171, AGU, Washington, D. C., 1987b.

Grunow, A.M., D. V. Kent, and I.W.D. Dalziel, New paleomagnetic data from Thurston Island: Implications for the tectonics of West Antarctica and Weddell Sea opening, J. Geophys. Res. 96, 17,93517,954, 1991.

Halpern, M., Rb-Sr total-rock and mineral ages from the Marguerite Bay area, Kohler Range and Fosdick Mountains, in Antarctic Geology and Geophysics, edited by Adie, R. J., pp. 197-204, Universitetsforlaget, Oslo, 1972.

Hole, M. J., and W. E. LeMasurier, Tectonic controls on the geochemical composition of Cenozoic mafic alkaline volcanic rocks from West Antarctica, Contrib. Mineral. Petrol., 117, 187-202, 1994.

Kellogg, K. S., Paleomagnetic evidence for oroclinal bending of the southern Antarctic Peninsula, Geol. Soc. Am. Bull., 91, 414-420, 1980.

Kellogg, K. S., A paleomagnetic investigation of rocks from the Ohio Range and the Dry Valleys, Transantarctic Mountains, Antarctica, N.Z. J. Geol. Geophys., 31, 77-85, 1988.

Kellogg, K. S., and P. D. Rowley, Structural geology and tectonics of the Orville Coast region, southern Antarctic Peninsula, Antarctica, U.S. Geol. Surv. Prof. Pap., 1498, 25 pp., 1989.

Kimbrough, D. L., A. J. Tulloch, E. Geary, D. S. Coombs, and C.A. Landis, Isotopic ages from the Nelson region of South Island New Zealand: Crustal structure and definition of the Median Tectonic Zone, Tectonophysics, 225, 433-448, 1993.

Kirschvink, J. L., The least-squares line and plane and the analysis of paleomagnetic data, Geophys. J. R. Astron. Soc., 62, 699-718, 1980.

LaBrecque, J. L., South Atlantic Ocean and adjacent continental margin, Atlas 13, in Ocean Margin Drilling Program, Regional Atlas Ser., 21 sheets, Marine Science International, Woods Hole, Mass., 1986.

LaBrecque, J. L., and P. F. Barker, The age of the Weddell basin, Nature, 290, 489-492, 1981.

Laird, M. G., The Late Proterozoic-Middle Palaeozoic rocks of Antarctica, in The Geology of Antarctica, edited by R. J. Tingey, pp. 74-119, Clarendon, Oxford, 1991.

Langel, R. A., International Geomagnetic Reference Field, 1991 revision: International Association of Geomagnetism and Aeronomy (IAGA) Division V, Working Group 8: Analysis of the main field and secular variation, Phys. Earth Planet. Inter., 70, 1-6, 1992.

Leat, P. T., B. C. Storey, and R. J. Pankhurst, Geochemistry of Palaeozoic-Mesozoic Pacific rim orogenic magmatism, Thurston Island area. West Antarctica, Antarct. Sci., 5, 281-296, 1993.

LeMasurier, W. E., and D. C. Rex, Rates of uplift and the scale of ice level instabilities recorded by volcanic rocks in Marie Byrd Land, West Antarctica, in Antarctic Earth Science, edited by R. L. Oliver, P. R. James, and J. B. Jago, pp. 663-670, Australian Academy of Science, Canberra, 1983.

LeMasurier, W. E., and D. C. Rex, The Marie Byrd Land volcanic province and its relation to the Cainozoic West Antarctic rift system, in The Geology of Antarctica, edited by R. J. Tingey, pp. 249-284, Clarendon, Oxford, 1991.

Livermore, R. A., and R. W. Woollett, Seafloor spreading in the Weddell Sea and southwest Atlantic since the Late Cretaceous, Earth Planet. Sci. Lett., 117, 475-495, 1993.

Longshaw, S. K., and D. H. Griffiths, A palaeomagnetic study of Jurassic rocks from the Antarctic Peninsula and its implications, $J$. Geol. Soc. London, 140, 945-954, 1983.

Lopatin, B. G., A. Y. Krylov, and O. A. Aliapyshev, Main tectonomagmatic stages of development of Marie Byrd Land and Eights Coast, West Antarctica according to radioactive data, Antarktika, 13, 52-61, 1974.

Martin, A. K., and C. J. H. Hartnady, Plate tectonic development of the southwest Indian Ocean, A revised reconstruction of East Antarctica and Africa, J. Geophys. Res., 91, 476-486, 1986

Mason, B., and S. R. Taylor, High-grade basement gneisses and granitoids in Westland, New Zealand, J. R. Soc. N. Z., 17, 115-138, 1987.

Mayes, C. L., L. A. Lawver, and D. T. Sandwell, Tectonic history and new isochron chart of the South Pacific, J. Geophys. Res., 95, 85438567, 1990.

McFadden, P. L., and F. J. Lowes, The discrimination of mean directions drawn from Fisher distributions, Geophys. J. R. Astron. Soc., 67, 1933, 1981.

McFadden, P. L., R. T. Merrill, M. W. McElhinny, and S. Lee, Reversals of the earth's magnetic field and temporal variations of the dynamo families, J. Geophys. Res., 96, 3923-3933, 1991.

Mukasa, S. B., I. W. D. Dalziel, and H. K. Brueckner, Zircon U-Pb constraints on the kinematic evolution of the northern Scotia Arc, Geol. Soc. Am. Abstr. Programs, 20, A12, 1988.

Palais, D. G., S. B. Mukasa, and S. D. Weaver, U-Pb and ${ }^{40} \mathrm{Ar} /{ }^{39} \mathrm{Ar}$ geochronology for plutons along the Ruppert and Hobbs Coasts, Marie Byrd Land, West Antarctica: Evidence for rapid transition from arc to rift-related magmatism (abstract), Eos Trans. AGU, 74 (16), Spring Meeting suppl., 123, 1993.

Pankhurst, R. J., and P. D. Rowley, Rb-Sr study of Cretaceous plutons from southern Antarctic Peninsula and eastern Ellsworth Land, Antarctica, in Geological Evolution of Antarctica, M. R. A. Thomson, J. A. Crame, and J. W. Thomson, pp. 387-394, Cambridge University Press, New York, 1991.

Pankhurst, R. J., I. L. Millar, A.M. Grunow, and B. C. Storey, The PreCenozoic magmatic history of the Thurston Island crustal block, West Antarctica, J. Geophys. Res., 98, 11,835-11,849, 1993.

Spörli, K. B., and C. Craddock, Geology of the Ruppert Coast, Marie Byrd Land, Antarctica, in Gondwana Five, edited by M. M. Cresswell and P. Vella, pp. 243-250, A. A. Balkema, Rotterdam, 1981.

Tranter, T. H., Accretion and subduction processes along the Pacific margin of Gondwana, central Alexander Island, in Geological Evolution of Antarctica, M. R. A. Thomson, J. A. Crame, and J. W. Thomson, pp. 437-441, Cambridge University Press, New York, 1991.

Van der Voo, R., Paleomagnetism of the Atlantic, Tethys and Iapetus Oceans, Cambridge University Press, New York, 1993.

Watts, D. R., and A.M. Bramall, Paleomagnetic evidence for a displaced terrain in western Antarctica, Nature, 293, 638-641, 1981.

Weaver, S. D., and R. J. Pankhurst, A precise Rb-Sr age for the Mandamus Igneous Complex, North Canterbury, and regional tectonic implications, N.Z. J. Geol, Geophys., 34, 341-345, 1991.

Weaver, S. D., J. D. Bradshaw, and C. J. Adams, Granitoids of the Ford Ranges, Marie Byrd Land, Antarctica, in Geological Evolution of Antarctica, M. R. A. Thomson, J. A. Crame, and J. W. Thomson, pp. 345-351, Cambridge University Press, New York, 1991.

Weaver, S. D., C. J. Adams, R. J. Pankhurst, and I. L. Gibson, Granites of Edward VII Peninsula, Marie Byrd Land: anorogenic magmatism related to Antarctic-New Zealand rifting, Trans. R. Soc. Edinburgh Earth Sci., 83, 281-290, 1992.

Weaver, S. D., B. C. Storey, R. J. Pankhurst, S. B. Mukasa, V. J. DiVenere, and J. D. Bradshaw, Antarctica - New Zealand rifting and Marie Byrd Land lithospheric magmatism linked to ridge subduction and mantle plume activity, Geology, 22, 811-814, 1994.

Zijderveld, J. D. A., AC demagnetization of rocks: Analysis of results, in Methods in Paleomagnetism, edited by D. W. Collinson, K. M. Creer, and S. K. Runcom, eds, pp. 254-286, Elsevier, New York, 1967.

I. W. D. Dalziel, Institute for Geophysics, University of Texas at Austin, Austin, TX 78759-8345

V. DiVenere and D. V. Kent, Lamont-Doherty Earth Observatory, P.O. Box 1000, Route 9W, Palisades, NY 10964-8000. (e-mail: sprite@ lamont.Ideo.columbia.edu

(Received July 20, 1994; revised December 28, 1994; accepted January 5, 1995.) 